\title{
Pacific geoduck (Panopea generosa) resilience to natural pH variation
}

\author{
Laura H. Spencer ${ }^{a}$, Micah Horwith ${ }^{b}$, Alexander T. Lowe ${ }^{c}$, Yaamini R. Venkataraman ${ }^{a}$, \\ Emma Timmins-Schiffman ${ }^{d}$, Brook L. Nunn ${ }^{d}$, Steven B. Roberts ${ }^{a}$ \\ aUniversity of Washington, School of Aquatic and Fishery Sciences, 1122 NE Boat St, Seattle, \\ WA 98105, United States \\ bWashington State Department of Natural Resources, 1111 Washington St SE, MS 47027 , \\ Olympia, WA 98504, United States \\ 'University of Washington, Biological Sciences, 24 Kincaid Hall, Seattle, WA 98105, United \\ States \\ dUniversity of Washington, Genome Sciences, William H. Foege Hall, 3720 15th Ave NE, \\ Seattle, WA 98195, United States
}

Corresponding Author: Steven B. Roberts, sr320@uw.edu 


\section{Abstract}

Pacific geoduck aquaculture is a growing industry, however, little is known about how geoduck respond to varying environmental conditions, or how the industry will fare under projected climate conditions. To understand how geoduck production may be impacted by low $\mathrm{pH}$ associated with ocean acidification, multi-faceted environmental heterogeneity needs to be included to understand species and community responses. In this study, eelgrass habitats and environmental heterogeneity across four estuarine bays were leveraged to examine low $\mathrm{pH}$ effects on geoduck under different natural regimes, using targeted proteomics to assess physiology. Juvenile geoduck were deployed in eelgrass and adjacent unvegetated habitats for 30 days while $\mathrm{pH}$, temperature, dissolved oxygen, and salinity were monitored. Across the four bays, $\mathrm{pH}$ was lower in unvegetated habitats compared to eelgrass habitats. However this did not impact geoduck growth, survival, or proteomic abundance patterns in gill tissue. Temperature and dissolved oxygen differences across all locations corresponded to differences in growth and targeted protein abundance patterns. Specifically, three protein abundance levels (trifunctional-enzyme $\beta$-subunit, puromycin-sensitive aminopeptidase, and heat shock protein $90-\alpha)$ and shell growth positively correlated with dissolved oxygen variability and inversely correlated with mean temperature. These results demonstrate that geoduck may be resilient to low $\mathrm{pH}$ in a natural setting, but other abiotic factors (i.e. temperature, dissolved oxygen variability) may have a greater influence on geoduck physiology. In addition this study contributes to the understanding of how eelgrass patches influences water chemistry.

\section{Key words}

Aquaculture, comparative physiology, ocean acidification, Panopea generosa, proteomics

\section{Introduction}

The Pacific geoduck, Panopea generosa, is native to the North American Pacific Coast and is a burgeoning aquaculture species with strong overseas demand as a luxury commodity (Coan et al. 2000; Shamshak and King 2015; Vadopalas et al. 2010). As the largest burrowing clam in the world, cultured geoduck reach upwards of $180 \mathrm{~mm}$ and are harvested after growing approximately 6-7 years in sub- or intertidal sediment (Vadopalas et al. 2015; Washington DNR website 2017; Washington Sea Grant 2013). The long grow-out period and high per-animal value highlights the importance of site selection for farmers to maximize investment; however, there remains a paucity of data on the optimal environmental conditions for geoduck aquaculture.

As marine calcifiers, geoduck may be vulnerable to ocean acidification due to their reliance on calcite and aragonite (forms of calcium carbonate) for shell secretion (Orr et al. 2005; Weiss et al. 2002), both of which become less biologically available as seawater $\mathrm{pH}$ declines with $\mathrm{pCO}_{2}$ enrichment (Feely et al. 2008). While there are no ocean acidification studies on Panopea clams to date, a growing body of research on marine calcifiers generally indicates that projected low pH will shift organisms' physiology to the detriment of species-wide 
abundances and distributions (Pörtner 2008; Pörtner and Farrell 2008). However, broad generalizations of how ocean acidification affects calcifiers are few due to varying $\mathrm{pH}$ sensitivity between taxa (Gazeau et al. 2007; Ries et al. 2009) and life stage (Kurihara 2008; Kroeker et al. 2010). For example, in the deeply studied oyster genus Crassostrea, Miller et al. (2009) found that larvae of two species varied in their response to elevated $\mathrm{pCO}_{2}$, as calcification rates were significantly reduced in the Eastern oyster (C. virginica), but the Suminoe oyster (C. ariakesnsis) showed no negative response. Thus, lessons learned from other bivalve species cannot directly be applied to geoduck.

The effect of low pH on cultured geoduck needs to be explored to help the aquaculture industry make informed site selection, selective breeding, and investment decisions. For practical application, geoduck ocean acidification studies should best replicate the natural environment in which they are grown. Ninety percent of global production occurs in the Puget Sound estuary of Washington State, where environmental drivers vary between subbasin, season, and diurnal cycle (Moore et al. 2008; Shamshak and King 2015). This habitat heterogeneity exposes geoduck to a variety of secondary stressors when outplanted. Similarly, there is substantial evidence that low $\mathrm{pH}$ is not occurring in isolation, but rather in conjunction with changes in other environmental drivers such as temperature (meta-analyses: Byrne and Przeslawski 2013; Harvey et al. 2013; Kroeker et al. 2013), dissolved oxygen (Gobler et al. 2014), and salinity (Przeslawski et al. 2015). Thus, single-stressor studies are limited in their predictive capacity of response to broad scale environmental change. For example, an additive, negative effect of elevated $\mathrm{pCO}_{2}$ and temperature was observed in juvenile giant fluted clam survival (Tridacna squamosa) (Watson et al. 2012). Another consideration is the incorporation of naturally-occurring diurnal $\mathrm{pH}$ variability into ocean acidification studies, as variable $\mathrm{pH}$ can have differing effects on marine calcifiers compared to persistent low pH (Review, Boyd et al. 2016). Porcelain crabs, for example, exposed to diurnally variable $\mathrm{pH}$ and temperature conditions demonstrated significantly slower metabolism than when crabs were exposed to less variability, or to temperature or $\mathrm{pH}$ variability alone (Paganini et al. 2014).

To best predict the effect of ocean acidification on geoduck aquaculture, this project deployed geoduck in variable environmental conditions and leveraged the natural $\mathrm{pH}$ differences between eelgrass and unvegetated habitats in Washington State estuaries. Ocean acidification studies are increasingly exploiting naturally low $\mathrm{pH}$ systems to monitor the environmental heterogeneity alongside test organisms, in hydrothermal vents (Tunnicliffe et al. 2009; Kerrison et al. 2011), shallow $\mathrm{CO}_{2}$ seeps (Duquette et al. 2017), coastal upwelling regions and eutrophic estuaries (Howarth et al. 2011; Thomsen et al. 2013). Compared to controlled laboratory studies, these deployment studies can uniquely incorporate natural ranges and daily cycles in air exposure, temperature, $\mathrm{pH}$, dissolved oxygen, salinity, and food availability. For instance, Ringwood and Keppler (2002) deployed hard clams (Mercenaria mercenaria) in the

78 Charleston Harbor estuary in South Carolina while collecting physical-chemical parameters.

79 They observed that while salinity was the primary determinant of growth, $\mathrm{pH}$ was also important particularly when salinity was low, and when $\mathrm{pH}$ dropped below 7.5, a nuanced finding that is more likely to be captured in a natural environment.

Estuaries along the United States Pacific Coast are ideal, natural mesocosms for examining the effect of ocean acidification on commercially vital calcifiers, as they contain dense macroalgae beds (Bulthuis 1995), environmental conditions that vary considerably 
between subbasins (Banas et al. 2004; Moore et al. 2008), and have rich communities of native and cultured shellfish (Dethier et al. 2006; Miller et al. 2009; Washington Sea Grant 2015). Furthermore, coastal estuaries have already shifted towards lower $\mathrm{pH}$ and warmer temperature averages, and are projected to continue along this trend (Abatzoglou et al. 2013; Busch et al. 2013; Doney et al. 2007; Feely et al. 2012, 2010, 2008; Mote and Salathé 2010). The buffering capacity of macroalgae (seagrass meadows, kelp forests) allows for block-designed experiments to examine the effect of $\mathrm{pH}$, while controlling for varying background environments and maintaining diurnal fluctuations (Middelboe and Hansen 2007; Palacios and Zimmerman 2007; Wahl et al. 2018).

In order to better inform geoduck aquaculture practices, we set out to examine how low $\mathrm{pH}$ and other natural variation in environmental conditions influence geoduck growth and physiology, using native eelgrass (Zostera marina) as a primary determinant of water chemistry. Physiology was evaluated with a unique two-phase proteomics approach using Selected Reaction Monitoring, with targets identified using Data Independent Acquisition, and selected based on prior environmental stress response studies.

Ocean acidification contributes to an elevation of reactive oxygen species in marine invertebrates (Tomanek 2015). Reactive oxygen species (ROS), or free-radicals, result in oxidative stress and in addition to low pH, higher ROS levels are associated with other environmental stressors including temperature, oxygen variability, salinity, and heavy metals (Review, Lushchak, 2011). Upregulation of anti-oxidants such as catalase, peroxiredoxins, and superoxide dismutase (among others) have consistently been observed in bivalves under low pH and heat stress (Tomanek et al. 2011; Matozzo et al. 2013; Hu et al. 2015), and under heavy metal exposure (Giarratano et al. 2014). In addition to ROS response, ocean acidification is thought to elicit a broader and generic molecular stress response in marine bivalves. Notably, the inducible heat shock proteins are associated with response to hypercapnia, in addition to acute heat, inflammation, and heavy metals, as they act as chaperones to recognize and bind to unfolded or improperly folded proteins (Bozaykut et al. 2014). Induction of HSP90, for example, has been universally observed thus far in bivalve species (Fabbri et al. 2008). Metabolic function is also altered under low $\mathrm{pH}$, hypoxia, and salinity stress, generally shifting to anaerobic metabolism to minimize the mitochondrial ROS production associated with aerobic metabolism (Tomanek 2014).

In addition to antioxidant, metabolic, and general stress-response proteins, this study targeted proteins involved in mitotic growth, detoxification, acid-base balance, and ion regulation (Table 2), all quantified simultaneously to characterize the physiological response in the Pacific geoduck under variable $\mathrm{pH}$ environments. This novel application demonstrates the advances in proteomic research and the potential it has to improve aquaculture production. 


\section{Methods}

\section{Experimental Design}

Panopea generosa juveniles $(14.0 \pm 0.85 \mathrm{~mm})$ were used in this experiment. Animals were of the same cohort, hatched from broodstock harvested from Puget Sound in Washington State, and reared in a commercial facility in Dabob Bay, WA in controlled conditions $\left(18^{\circ} \mathrm{C}\right.$, salinity of 30ppt and pH 8.2). Geoduck were out-planted in four bays throughout Western Washington State from June 21 to July 21, 2016: Fidalgo Bay (FB), Port Gamble Bay (PG), and Case Inlet (Cl) in Puget Sound, and Willapa Bay (WB) located off the southwest Pacific Coast of Washington (Table 1, Figure 1). All locations were selected based on the criteria that both $Z$. marina eelgrass beds ("eelgrass"), and unvegetated sediment ("unvegetated") habitats were present. Clams were placed in $10 \mathrm{~cm}$ diameter polymerizing vinyl chloride (PVC) pipes buried in sediment with $5 \mathrm{~cm}$ exposed; this method replicates aquaculture techniques. Five clams were placed in each of the 3 tubes in both the eelgrass and unvegetated habitat, with a total of 30 clams across 6 tubes per bay. Pipes were covered with a protective mesh exclosure to limit predation. The replicate structures surrounded and were equidistant to a suite of water quality sensors capturing pH (Honeywell Durafet II Electrode, in custom-built housing), salinity (via conductivity, Dataflow Systems Ltd. Odyssey Conductivity and Temperature Logger), dissolved oxygen (Precision Measurement Engineering MiniDOT Logger), and temperature (via dissolved oxygen probes). Sensors were modified for submersible, autonomous data collection, and logged at 10-minute intervals for the duration of the 30-day outplant.

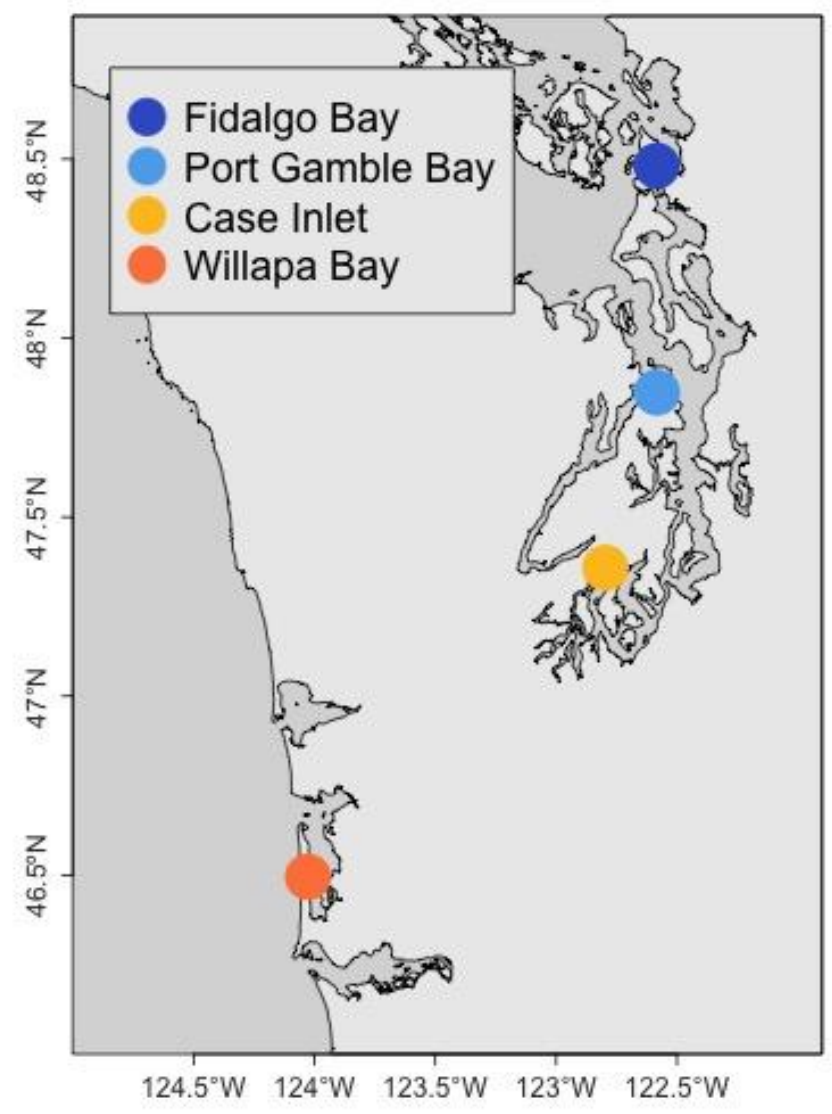

Figure 1: Geoduck juveniles were deployed for 30 days in 2 habitats (eelgrass beds, unvegetated) within 4 bays in Western Washington State 


\begin{tabular}{|l|l|l|}
\hline Bay & Eelgrass Habitat & Unvegetated Habitat \\
\hline Fidalgo Bay & $\begin{array}{l}48^{\circ} 28^{\prime} 52.8312^{\prime \prime} \mathrm{N} \\
122^{\circ} 35^{\prime} 0.7044^{\prime \prime} \mathrm{W}\end{array}$ & $\begin{array}{l}48^{\circ} 28^{\prime} 54.0876^{\prime \prime} \mathrm{N} \\
122^{\circ} 35^{\prime} 0.708^{\prime \prime} \mathrm{W}\end{array}$ \\
\hline $\begin{array}{l}\text { Port Gamble } \\
\text { Bay }\end{array}$ & $\begin{array}{l}47^{\circ} 50^{\prime} 52.7388^{\prime \prime} \mathrm{N} \\
122^{\circ} 34^{\prime} 58.5084^{\prime \prime} \mathrm{W}\end{array}$ & $\begin{array}{l}47^{\circ} 50^{\prime} 33.6336^{\prime \prime} \mathrm{N} \\
122^{\circ} 35^{\prime} 1.7952^{\prime \prime} \mathrm{W}\end{array}$ \\
\hline Case Inlet & $\begin{array}{l}47^{\circ} 21^{\prime} 30.3808^{\prime \prime} \mathrm{N} \\
122^{\circ} 47^{\prime} 47.2182^{\prime \prime} \mathrm{W}\end{array}$ & $\begin{array}{l}47^{\circ} 21^{\prime} 28.5721^{\prime \prime} \mathrm{N} \\
122^{\circ} 47^{\prime} 44.7457^{\prime \prime} \mathrm{W}\end{array}$ \\
\hline Willapa Bay & $\begin{array}{l}46^{\circ} 29^{\prime} 42.288^{\prime \prime} \mathrm{N} \\
124^{\circ} 11^{\prime} 35.472^{\prime \prime} \mathrm{W}\end{array}$ & \begin{tabular}{l}
$46^{\circ} 29^{\prime} 40.124^{\prime \prime} \mathrm{N}$ \\
$124^{\circ} 1$ \\
\hline
\end{tabular}
\end{tabular}

Table 1: Coordinates for geoduck placement.

\section{Collection and Sampling}

164 Animals were collected during low tide and transferred on wet ice to shore where mortality and size were recorded. Live animals were dissected, and ctenidia tissue was isolated and flashfrozen in an ethanol-dry ice bath. Ctenidia was selected for proteomic analysis due to its direct interaction with the environment, importance in gas and ion regulation, and its implication in environmental stress response (Timmins-Schiffman et al., 2014, Matozzo et al. 2013, Zhang et al. 2015, Thompson et al. 2015). During sampling all instruments were sterilized between samples with bleach then ethanol, and rinsed with nanopure water. Samples were held on dry ice while transported back to the lab and stored at $-80^{\circ} \mathrm{C}$.

\section{Environmental and Growth Data}

174 Temperature, $\mathrm{pH}$, salinity and dissolved oxygen data were compared between outplant

175 locations. Outliers for all environmental parameters were removed, as determined using Tukey Interquartile Range (IQR) method (Tukey 1977), excluding data outside the inner fence (1.5*IQR). Tidal charts from WWW Tide/Current Predictor and salinity data (<20ppt) were also used to remove $\mathrm{DO}$ and $\mathrm{pH}$ data corresponding to periods of tidal exposure. Four probe failures occurred during deployment (Supplemental Table 1, failed) and these data were not included in the analysis ( $\mathrm{pH}$ at Port Gamble-eelgrass, salinity at Port Gamble-unvegetated \& Case Inleteelgrass, DO in Fidalgo Bay-eelgrass). Salinity data from two additional locations was not reliably measured (Willapa Bay-unvegetated, Fidalgo Bay-unvegetated), so habitat comparisons were not performed for salinity data. For each parameter at each location, daily mean and daily standard deviation time series were calculated. Relative growth for each animal was determined as $\left(L_{f}-L_{i}\right)$, where $L_{f}=$ final geoduck shell length, $L_{i}=$ average initial geoduck shell length within each exclosure $(n=5)$. Differences in growth and environmental parameters between habitat 
were compared using 2-way analysis of variance (ANOVA) applied to regression models (value $\sim$ habitat*bay). Bays and ad-hoc regions (north vs. south bays) were tested using 1-way ANOVA. Pairwise comparisons were tested with the t-statistic. Significance for all tests was defined as $\mathrm{P}<0.05$, corrected for multiple comparisons using the Bonferroni correction.

\section{Protein Analysis}

\section{Protein Preparation}

Relative protein abundance was ultimately assessed in a two-phase proteomics approach using Selected Reaction Monitoring (SRM), with targets identified using Data Independent Acquisition (DIA). Tissues were prepared separately for DIA and SRM, both following the protocol in Timmins-Schiffman et al. (2014) with a few exceptions. For DIA, 8 ctenidia tissue samples were analyzed, one sample from each location and habitat: FB-eelgrass (G048), FB-unvegetated (G058), PGB-eelgrass (G077), PGB-unvegetated (G068), Cl-eelgrass (G010), Cl-unvegetated (G018), WB-eelgrass (G131), WB-unvegetated (G119). For SRM, new ctenidia samples were examined, 12 individuals per bay (Fidalgo Bay, Port Gamble Bay, Case Inlet, Willapa Bay), with 6 from each habitat (eelgrass, unvegetated) for 48 samples total. Tissue was homogenized with sterile plastic pestle in $100 \mu \mathrm{l}$ lysis buffer $\left(50 \mathrm{mM} \mathrm{NH}_{4} \mathrm{HCO}_{3}, 6 \mathrm{M}\right.$ urea solution) and sonicated with Sonic Dismembrator (Fisher Scientific, Model 120 ) at $50 \%$ amplitude for ten seconds, three times. Protein concentration was quantified via Pierce ${ }^{\mathrm{TM}}$ BCA Protein Assay Kit (ThermoFisher Scientific, Waltham, MA USA).

\section{Mini-Trypsin Digestion}

Aliquots of protein (30 $\mu \mathrm{g}$ for DIA, $100 \mu \mathrm{g}$ for SRM) were suspended in Lysis Buffer ( $50 \mathrm{mM}$ $\mathrm{NH}_{4} \mathrm{HCO}_{3}+6 \mathrm{M}$ urea solution) to a total volume of $100 \mu$ followed by: 1) a 1 hour incubation at

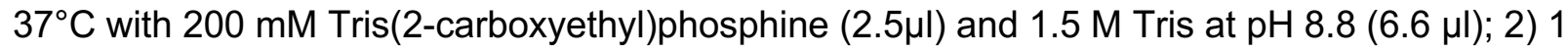
hour at room temperature in dark with $200 \mathrm{mM}$ iodoacetamide $(20 \mu \mathrm{l})$; 3) 1 hour at room temperature with $200 \mathrm{mM}$ diothiothreitol $(20 \mu \mathrm{l}) ; 4) 1$ hour at room temperature with $2 \mathrm{ug} / \mathrm{\mu l}$ Lysyl Endopeptidase (Lys-C, Wako Chemicals) $(3.3 \mu \mathrm{g})$; 5 ) overnight at room temperature in $25 \mathrm{mM}$ $\mathrm{NH}_{4} \mathrm{HCO}_{3}(800 \mu \mathrm{l})+$ high pressure liquid chromatography grade methanol $(200 \mu \mathrm{l})+$ Pierce Trypsin Protease, MS Grade (1 ug/ $\mu \mathrm{l}$, Thermo Scientific) at 1:30 enzyme:protein ratio $(3.3 \mu \mathrm{g})$. Samples were evaporated to near dryness at $4^{\circ} \mathrm{C}$ using a CentriVap Benchtop Vacuum Concentrator.

\section{Desalting}

Samples were desalted to isolate peptides using MacroSpin Columns (Nest Group, 50-450 $\mu$, Peptide Protein C18). Peptides were reconstituted in $5 \%$ acetonitrile $+0.1 \%$ trifluoroacetic acid (TFA) 
$(100 \mu \mathrm{l})$, then $10 \%$ formic acid $(70 \mu \mathrm{l})$ was added to achieve $\mathrm{pH} \leq 2$. Columns were washed with $60 \%$ acetonitrile $+0.1 \%$ TFA (Solvent A, $200 \mu \mathrm{l}$ ) four times, then equilibrated with $5 \%$ acetonitrile $+0.1 \%$ TFA (Solvent B, $200 \mu$ ) three times. Peptides were bound to the column by running the digest through the column twice, followed by peptide elution with two additions each of Solvent A (100 ul). Columns were spun for 3 minutes at $3000 \mathrm{rpm}$ on VWR Galaxy 16DH digital microcentrifuge at each stage. Samples were evaporated to near dryness at $4{ }^{\circ} \mathrm{C}$, then reconstituted in the Final Solvent ( $3 \%$ acetonitrile $+0.1 \%$ formic acid) $(60 \mu \mathrm{l}$ for $0.5 \mu \mathrm{g} / \mu \mathrm{l}$ final concentration of protein, and $50 \mu \mathrm{l}$ for $2 \mu \mathrm{g} / \mu \mathrm{l}$ final concentration for DIA \& SRM, respectively).

\section{Peptide sample preparation and internal standard}

Final mixtures for mass spectrometry included $3.13 \mathrm{fmol} / \mu \mathrm{l}$ Peptide Retention Time Calibration mixture (PRTC), $0.33 \mu \mathrm{g} / \mu \mathrm{l}$ and $0.5 \mu \mathrm{g} / \mu \mathrm{l}$ peptides for DIA and SRM, respectively, in Final Solvent for $15 \mu \mathrm{l}$ total volume. To confirm that peptides were quantified correctly in SRM, $10 \mu \mathrm{g}$ from 5 randomly selected geoduck peptide samples were pooled, and 8 dilutions were prepared by combining with oyster peptides at known percentages of total protein content $(10 \%, 13.3 \%$, $20 \%, 40 \%, 60 \%, 80 \%, 87.7 \%, 90 \%$ ) and analyzed alongside other samples.

\section{Data Independent Acquisition}

\section{Data acquisition}

243 Data Independent Acquisition (DIA) was performed to assess global protein abundance patterns and to identify consistently detectable peptides for SRM targets. Eight samples, one per deployment location, were analyzed in technical duplicates via liquid chromatography tandem mass spectrometry (LC-MS/MS) with the Thermo Scientific ${ }^{\mathrm{TM}}$ Orbitrap Fusion Lumos ${ }^{\mathrm{TM}}$ Tribrid $^{\mathrm{TM}}$. Prior to sample analysis, the $30 \mathrm{~cm}$ analytical column and $3 \mathrm{~cm}$ trap were packed inhouse with with C18 beads (Dr. Maisch HPLC, Germany, $0.3 \mu \mathrm{m}$ ). For each sample, $3 \mu \mathrm{l}$ of geoduck peptides $(1.0 \mu \mathrm{g})+$ PRTC peptides was injected and analyzed in MS1 over 400-900 $\mathrm{m} / \mathrm{z}$ range, in $5 \mathrm{~m} / \mathrm{z}$ overlapping isolation windows from $450-850 \mathrm{~m} / \mathrm{z}$ with $15 \mathrm{~K}$ resolution in MS2. Final Solvent blanks were run between each geoduck peptide injection to ensure against peptide carry-over. Lumos MS/MS method and sequence files are available in the project repository (Spencer et al. 2019), and data are available via ProteomeXchange with identifier PXD012266.

\section{Protein identification and analysis}

Proteins were inferred using an assembled, translated, and annotated $P$. generosa gonad transcriptome (combined male and female) (Timmins-Schiffman et al. 2017; DOI: 10.17605/OSF.IO/3XF6M). Transcriptome peptides were queried against those detected by the Lumos MS/MS using PEptide-Centric Analysis (PECAN) (Ting 2017) to create a peptide spectral library (.blib type file). DIA raw files were first demultiplexed using MSConvert (ProteoWizard version 3.0.10738, 2017-04-12) (Chambers et al. 2012) with filters set to vendor centroiding for msLevels [2,3] (--"peakPicking true 1-2"), and optimizing overlapping spectra ("demultiplex optimization-overlap only"). The transcriptome fasta file was tryptic digested in silico in Protein Digestion Simulator (version 2.2.6471.25262), set to Fully Tryptic from 400-6000 fragment mass range, 5 minimum residues allowed, 3 maximum missed cleavages and peak 
matching thresholds set to $5 \mathrm{ppm}$ mass tolerance, and $0.05 \mathrm{ppm}$ NET tolerance. Skyline version 3.7.0.11317 (MacLean et al. 2010) automatically selected transition peaks and quantified peptide abundances using peak area integration. All PRTC peptide peak selections were manually verified and corrected. Skyline peak selection error rate was calculated by manually checking chromatograms from 100 proteins across all DIA samples. Auto-selected peaks were assigned correct or incorrect selection based on transition retention time alignment across replicates, using PRTC peptides as a reference. Transition peak area, which is assumed to correlate to peptide transition abundance, was exported from Skyline for analysis in $\mathrm{R}$ version 2.4-3 (R Core Team 2016). Abundance was normalized by the total ion current (TIC) for each injection. Technical replicate, bay and habitat differences were assessed to inform SRM analysis via non-metric multidimensional scaling (NMDS) analysis using 'metaNMDS' in the vegan package (Oksanen et al. 2016) on $\log (x+1)$ transformed abundances using a Bray-Curtis dissimilarity matrix. Technical replicate spectral abundances clustered together on NMDS plots, thus were averaged across each sample. Bay and habitat differences in global abundance were visually but not quantitatively analyzed (Supplemental Figure 4).

\section{Selected Reaction Monitoring}

\section{Target selection}

284 Thirteen proteins were selected for SRM targets (Table 2). First, candidate proteins ( 200) were selected based on biological function listed in the Universal Protein Knowledgebase (Apweiler et al. 2004) and evidence of stress response in bivalves from the scientific literature. Candidate proteins were screened for detectability using DIA results. Selected proteins were required to have $\geq 3$ high quality peptides, each with $\geq 3$ transitions, present in all DIA biological and technical replicate data. Quality peptides had uniform peak morphology and retention time in Skyline across replicates. A total of 49 peptides were selected for SRM: 39 to quantify 13 target proteins (116 transitions), and 10 for internal standard (30 transitions). A full list of transition targets are published on https://panoramaweb.org/e0TsuK.url and available in the project

293 repository (Spencer et al. 2019).

\begin{tabular}{|c|c|c|}
\hline SRM Protein Targets & $\begin{array}{c}\text { Top Blast Hit Uniprot SpID } \\
\text { (E-value) }\end{array}$ & Peptide sequences \\
\hline heat shock protein 90-alpha & $\begin{array}{l}\mathrm{P} 30946 \\
\quad(0)\end{array}$ & $\begin{array}{l}\text { GVVDSEDLPLNISR } \\
\text { EVVQSSAFVER } \\
\text { DSSTMGYMAAK }\end{array}$ \\
\hline heat shock protein 70 & $\begin{array}{l}\text { Q91233 } \\
\quad(0)\end{array}$ & $\begin{array}{l}\text { TTPSYVAFNDTER } \\
\text { NAVVTVPAYFNDAQR } \\
\text { IINEPTAAALAYGLDK }\end{array}$ \\
\hline superoxide dismutase & $\begin{array}{l}\text { P28757 } \\
(1 e-57)\end{array}$ & $\begin{array}{c}\text { THGAPTDEER } \\
\text { ISLTGPHSIIGR } \\
\text { TIVVHADVDDLGK } \\
\end{array}$ \\
\hline catalase & $\begin{array}{l}\mathrm{P} 00432 \\
(0)\end{array}$ & $\begin{array}{c}\text { AGELGGSDPDYAMR } \\
\text { LYSYSDTHR } \\
\text { LTANIAGHLIGAQEFIQK }\end{array}$ \\
\hline peroxiredoxin-1 & $\begin{array}{l}\text { Q6B4U9 } \\
(2 \mathrm{e}-95)\end{array}$ & $\begin{array}{c}\text { ALFIIDDK } \\
\text { QITMNDLPVGR }\end{array}$ \\
\hline
\end{tabular}




\begin{tabular}{|c|c|c|}
\hline & & LVQAFQFTDK \\
\hline puromycin-sensitive aminopeptidase & $\begin{array}{l}\text { Q11011 } \\
(0)\end{array}$ & $\begin{array}{l}\text { LNSGSVGVYR } \\
\text { SLTENFVTEEQAK } \\
\text { SIQQSVENIR }\end{array}$ \\
\hline protein disulfide-isomerase & $\begin{array}{l}\mathrm{P} 07237 \\
(0)\end{array}$ & $\begin{array}{c}\text { NNKPSDYQGGR } \\
\text { DNVVVIGFFK } \\
\text { MDSTANEVEDVK } \\
\end{array}$ \\
\hline ras-related protein rab-11B & $\begin{array}{l}\text { O35509 } \\
(1 \mathrm{e}-85)\end{array}$ & $\begin{array}{l}\text { VVLVGDSGVGK } \\
\text { STIGVEFATR } \\
\text { AQLWDTAGQER }\end{array}$ \\
\hline $\begin{array}{l}\text { sodium/potassium-transporting ATPase } \\
\text { subunit alpha }\end{array}$ & $\begin{array}{l}\text { Q13733 } \\
(9 e-62)\end{array}$ & $\begin{array}{l}\text { TVIEPMAGDGLR } \\
\text { MVTGDNVNTAR } \\
\text { LLDQVWPDLR }\end{array}$ \\
\hline glycogen phosphorylase (muscle form) & $\begin{array}{l}\text { Q9WUB3 } \\
(0)\end{array}$ & $\begin{array}{c}\text { APNSFNLR } \\
\text { VLYPNDNFFEGK } \\
\text { TSFDAFPDK } \\
\end{array}$ \\
\hline $\begin{array}{c}\text { trifunctional enzyme } \\
\beta \text {-Subunit (mitochondrial) }\end{array}$ & $\begin{array}{l}\mathrm{O} 46629 \\
(0)\end{array}$ & \begin{tabular}{|c|} 
AAQDNGLLTDVLAYK \\
ALELGLKPK \\
FNLWGGSLSLGHPFGATGV \\
R
\end{tabular} \\
\hline cytochrome P450 & $\begin{array}{l}\mathrm{P} 00185 \\
(7 \mathrm{e}-39)\end{array}$ & $\begin{array}{l}\text { IITRPFNVNGLLAYDSR } \\
\text { WLDESGVFLPEEHPSR } \\
\text { QSLLPFGATGPR }\end{array}$ \\
\hline arachidonate 5-lipoxygenase & $\begin{array}{l}\text { P09917 } \\
\text { (2e-94) }\end{array}$ & $\begin{array}{c}\text { APGLPAQIK } \\
\text { MDVEGTLPEDLK } \\
\text { GLGLGGVPGQNGK }\end{array}$ \\
\hline
\end{tabular}

Table 2: SRM proteins targets selected based on biological function and detectability across DIA samples

\section{Data acquisition}

298 SRM samples were analyzed on a Vantage Triple-Stage Quadrupole Mass Spectrometer (Thermo Scientific, San Jose, CA, USA), and injected by a nanoACQUITY UPLC ${ }^{\circledR}$ system (Waters, Milford, MA, USA) at random in two technical replicates. For each sample, $2 \mu \mathrm{l}$ of peptides + PRTC solution containing $1.0 \mu \mathrm{g}$ of geoduck peptides was injected, trapped on a 3 $\mathrm{cm}$ pre-column and separated on a $30 \mathrm{~cm}$ analytical column using a chromatography gradient of $2-60 \%$ acetonitrile over 60 minutes. Columns were prepared as in DIA (above). Samples were injected in randomized groups of 5, followed by a Peptide Retention Time Calibration (PRTC) plus bovine serum albumin peptides (BSA) standard, then Final Solvent blank. Vantage MS sequence and method files are available in the project repository (Spencer et al. 2019).

\section{Protein identification and quality assurance}

Peptides were identified and quantified via Skyline-daily version 3.7.1.11357 (MacLean et al. 2010). Raw SRM files were imported into a Skyline-daily project along with the target protein transitions, and the spectral library (.blib file) created previously in the DIA Protein Identification step. SRM peptides were verified by regressing PRTC peptide retention time (RT) in SRM against retention time in DIA. A fitted model from PRTC peptides predicted RT of protein target peptides. Where necessary, peak selection and boundaries were manually adjusted for SRM peptide chromatograms, and actual RT were regressed against predict RT to confirm correct selection ( $F(1,38)$ : 5768, p-value: <2.2e-16, Adjusted R-squared: 0.9933) (Supplemental Figure 
5). Transition peak area, defined henceforth as abundance, was exported from Skyline for further analysis in $\mathrm{R}$ (R Core Team 2016). Abundance results from the separate serial dilution samples were used to remove peptides that did not adhere to the dilution curve. Briefly, dilution abundances (exported from Skyline) for each transition were normalized by the most dilute sample abundance, then regressed against predicted ratios. Peptides with slope coefficient $0.2<x<1.5$ and adjusted $R^{2}>0.7$ were included in analysis. Ten of the 39 peptides were discarded from the dataset based on dilution standards results (Supplemental Figure 6). To determine and remove disparate technical replicates, NMDS analysis was performed as described above. Technical replicates with ordination distance $>0.2$ were removed, and only samples with two technical replicates were preserved for analysis (Supplemental Figure 7). Thirteen technical replicates from different samples and all replicates from three sample were discarded, for $84 \%$ technical replicate and $94 \%$ biological replicate retention. Within samples, transitions with coefficients of variation $(\mathrm{CV})>40 \%$ between technical replicates were also discarded ( $2 \%$ of all transitions across 21 samples). In final dataset for differential analysis, 10 proteins, 26 peptides, and 77 transitions were retained. Mean transition abundance was calculated for replicates, with zero in the place of n/a values, which Skyline generates for replicates without peaks. Transition abundances within each peptide were summed for a total peptide abundance before analyzing for differential abundance.

\section{Differential protein analysis}

After data quality screening, peptide abundance was analyzed for differences between locations and habitats. NMDS plots visualized patterns in peptide abundances by bay and habitat as described above. Global peptide abundance was compared between bay and habitats using two-way ANOVA on log-transformed abundances. For protein-specific comparisons, peptide abundances were grouped by protein, box-cox transformed (Box and Cox 1964) and normality confirmed via qqplot (Wickham 2017). Two-way ANOVA tested abundances for each protein between eelgrass and unvegetated habitats within and between bays. Pairwise comparisons for differentially abundant proteins were tested with the t-statistic. Peptides within proteins were regressed against each other to confirm stable abundance patterns. For all statistical analyses, significance was defined as alpha $\leq 0.05$, corrected for multiple comparisons using the Bonferroni correction.

\section{Correlative analysis}

To understand how environmental and biometric parameters covaried, Pearson's productmoment correlation and scatter plots were assessed between protein abundances, growth, and environmental summary statistics (mean and variance). Each protein was assessed independently. Due to salinity probe malfunction, salinity data were not included in correlation tests.

All analyses were performed in RStudio version 1.1.383 (R Core Team 2016). $R$ scripts and notebooks (Spencer et al. 2019), raw data (ProteomeXchange PXD012266), and Skyline project files (https://panoramaweb.org/e0TsuK.url) are publicly available. 


\section{Results}

\section{Environmental \& Growth Data}

361 Mean $\mathrm{pH}$ differed significantly between habitats across all bays $(F(1,206)=180.0, p=1.1 e-28)$

362 (Figure 2). During the deployment, $\mathrm{pH}$ was recorded from 6.71 to 8.34, with mean $\mathrm{pH} 7.86 \pm 0.15$

363 in eelgrass, and 7.51 \pm 0.25 in unvegetated habitats (means are for all locations). Variability in $\mathrm{pH}$

364 was significantly different among bays $(F(3,206=43.8, p=1.0 e-20)$. Variability did not differ

365 between habitats across all bays, but differences were detected between habitats within Case

366 Inlet and within Willapa Bay (less variable in eelgrass, Supplemental Table 1). The locations

367 with the highest and lowest daily mean $\mathrm{pH}$ were Fidalgo Bay-eelgrass (7.90 \pm 0.19$)$ and Port

368 Gamble Bay-unvegetated, respectively (7.32 \pm 0.25$)$. On average across all locations, $\mathrm{pH}$ fluctuated daily by $0.46 \pm 0.23 \mathrm{pH}$ units. Considerable heterogeneity among bays was observed in the other environmental parameters. Mean temperature was significantly different among all bays $(F(3,236)=129.4, p=2.2 e-48)$, and temperature decreased with latitude (coldest in northernmost Fidalgo Bay, warmest in southernmost Willapa bay). Temperature did not differ between habitats within bays (Supplemental Figure 1). Dissolved oxygen (DO) varied among bays in both daily standard deviation $(F(3,210)=132.8, p=4.6 e-47)$ and mean $(F(3,210)=56.7$, $p=1.1 e-25)$. DO variability was substantially higher in the two northern bays (SD was 5.6 and $3.9 \mathrm{mg} / \mathrm{L}$ in FB, PGB), as compared to the southern bays (2.5 and $1.4 \mathrm{mg} / \mathrm{L}$ in $\mathrm{Cl}, \mathrm{WB})$. Across all bays, DO variability did not differ between habitats, but did differ within Case Inlet and Fidalgo Bay (Supplemental Table 1 \& Figure 2). Mean salinity differed by bay $(F(3,136)=254.3$, $\mathrm{p}=2.3 \mathrm{e}-54$ ), with the largest differences between Fidalgo Bay (mean $29.9 \mathrm{ppt}$ ) and the other three bays (mean 23.4-27.0 ppt) (Supplemental Figure 3). Growth significantly differed between northern and southern bays $(F(1,97)=54.8, P=4.9-11)$, but not between habitats either within or across all bays. Geoduck in Fidalgo Bay and Port Gamble Bay grew larger compared to Willapa Bay, and Case Inlet (Figure 3). Survival did not differ among locations (Supplemental Table 1). 
bioRxiv preprint doi: https://doi.org/10.1101/432542; this version posted January 26,2019 . The copyright holder for this preprint (which was not certified by peer review) is the author/funder, who has granted bioRxiv a license to display the preprint in perpetuity. It is made available under aCC-BY-ND 4.0 International license.

\section{Fidalgo Bay daily mean $\mathrm{pH}$}

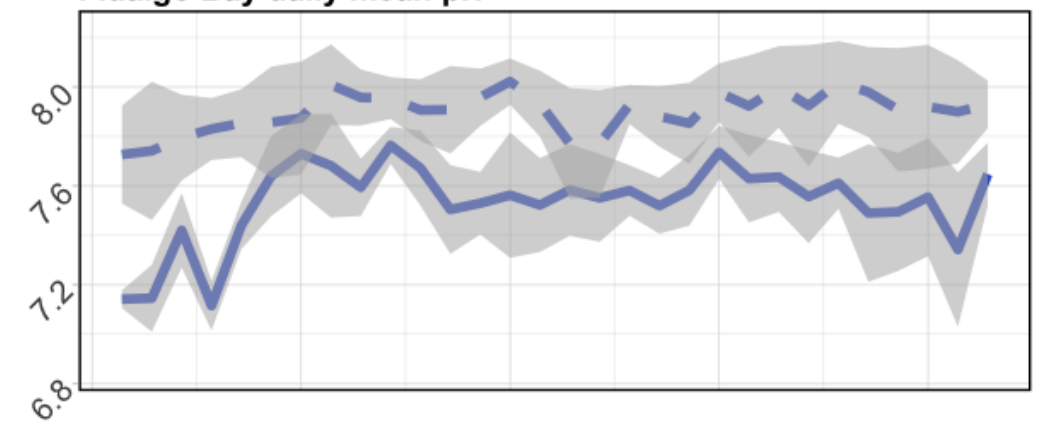

Port Gamble Bay daily mean pH
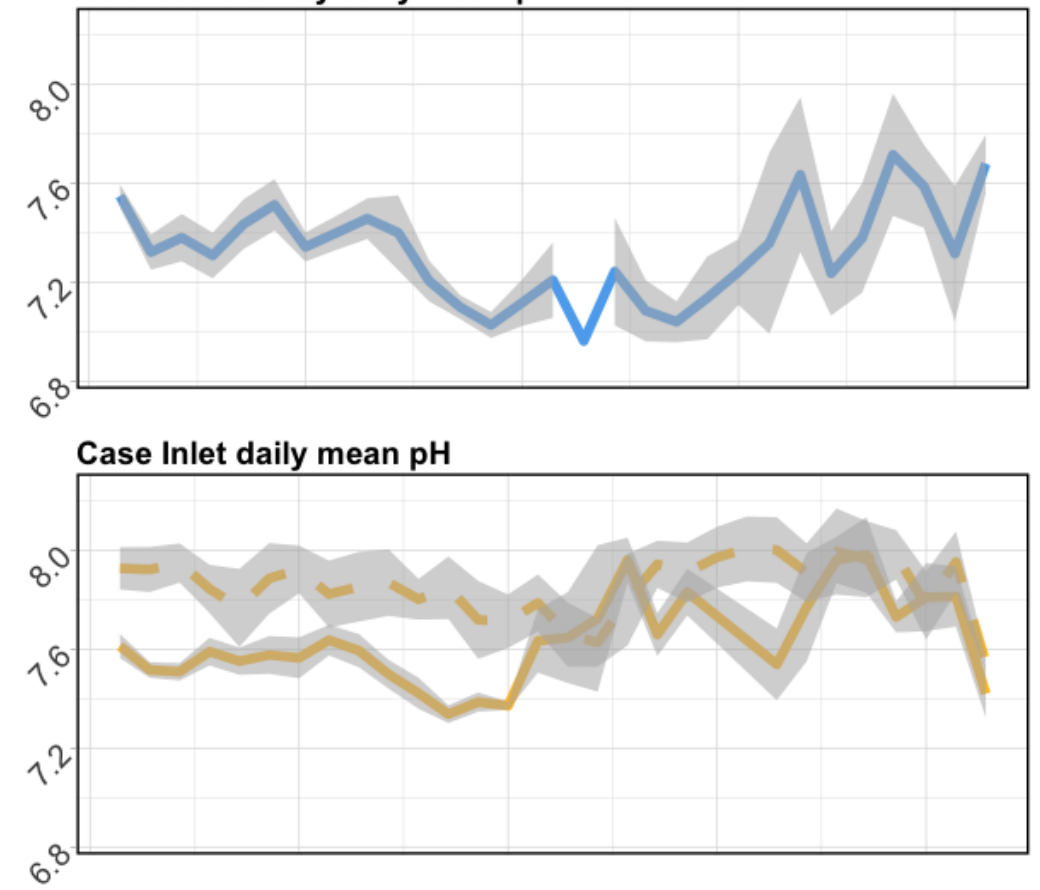

Willapa Bay daily mean pH

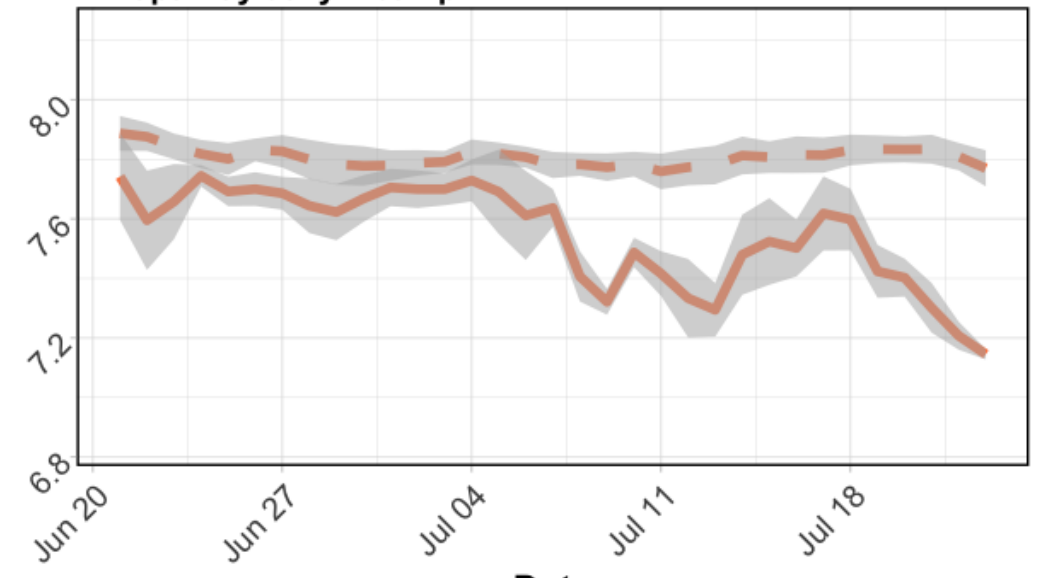

Date

Figure 2: Daily mean $\mathrm{pH}$ in eelgrass (dashed lines) and unvegetated (solid lines) across bays during geoduck deployment. Gray ribbons denote daily standard deviation. Data from Port Gamble bay eelgrass are not included due to probe failure. 


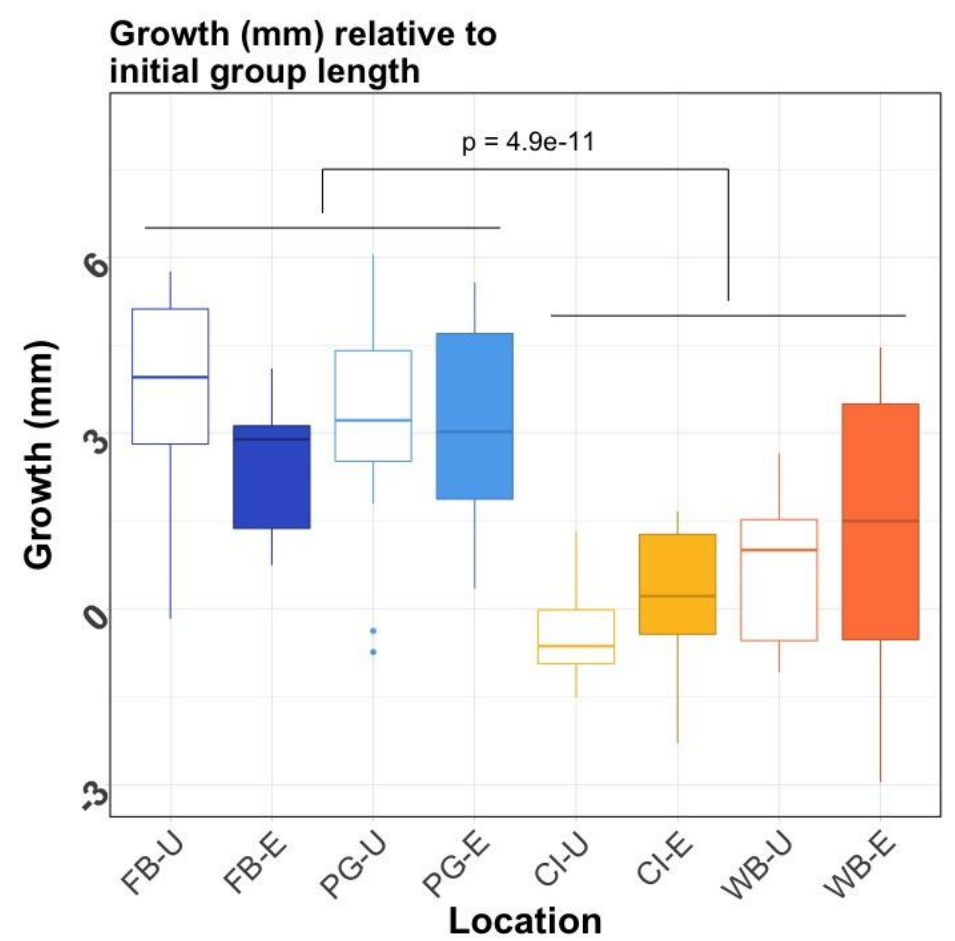

Figure 3: Geoduck shell growth after 30 days across Willapa Bay (WB), Case Inlet (CI), Port Gamble Bay (PG), and Fidalgo Bay (FB), where $-U$ and $-E$ represent unvegetated (empty boxes) and eelgrass habitats (filled boxes), respectively. Growth is relative to the mean initial shell length within deployment groups ( $n=5$ per group, 3 groups per location). Boxes contain all biological replicates lying within the interquartile range (IQR), with median growth indicated by line in middle of boxes. Whiskers extend to the largest value no greater than $1.5^{\star} I Q R$, and dots indicate outliers beyond $1.5^{\star} I Q R$. Geoduck that did not survive deployment are not included. Growth differed significantly between southern bays (WB, Cl) and northern bays (PG, FB) $(p=4.9 e-11)$ but not between habitats within bays.

\section{5}

386

387

388

389

390

391

392

393

394

395

396

397

398

399

400

\section{Protein Detection and Variance}

In DIA, a total of 298,345 peptide transitions were detected from 30,659 distinct peptides across the 8 samples (one sample per habitat from each bay). These peptides were associated with 8,077 proteins, and more than half of the proteins $(4,252)$ were annotated using Universal Protein Resource database (UniProt). Automated peak selection (Skyline) success rate was $71 \%$.

In SRM, the final dataset after screening included 10 proteins, 26 peptides, and 77 transitions. The 3 proteins fully removed from the dataset were heat shock protein 70 , peroxiredoxin-1, and ras-related rab. The SRM mean coefficients of variation (CV) of technical replicate abundances across all transitions decreased from $18.2 \%$ to $9.6 \%$ after screening. Transition abundance $\mathrm{CV}$ within bays ranged from $24.9 \%$ to $83.2 \%$ with mean $50.1 \%$, and within deployment locations CV ranged from $11.6 \%$ to $93.0 \%$ with mean $48.9 \%$ (Supplemental Table 3). Within proteins, regression analysis indicated that peptide abundances from the same protein differed slightly, however the relative abundances across samples was consistent. This indicates a small degree of background variability in peptide detection, digestion, or stability within proteins that applied to all samples (Pep1xPep2: $\mathrm{R}_{\mathrm{A}}^{2}=0.985$, coefficient $=0.682$; 
Pep1xPep3: $R_{A}^{2}=0.990$, coefficient=0.954; Pep2xPep3: $R_{A}^{2}=0.990$, coefficient=0.954).

\section{Protein Abundance Differences}

None of the 10 targeted proteins were differentially abundant between habitats within or across bays (Figure 4, Supplemental Table 2). NMDS plots of all transitions in DIA and those targeted in SRM revealed clustering of overall proteomic response by bay (Supplemental Figures 4 \& 8). In SRM, Fidalgo Bay and Port Gamble Bay samples clustered together (henceforth "northern bays"), and some overlap between Case Inlet and Willapa Bay ("southern bays") indicated similar protein abundances within these ad-hoc regions (Supplemental Figure 8). This was verified from the ANOVA results, which detected significant abundance differences between northern and southern bays for three proteins: HSP90- $\alpha$ (HSP90) $(F(1,133)=20.5, p$-adj=1.8e$4)$, trifunctional-enzyme subunit $\beta$-subunit $(T E \beta)(F(1,88)=11.1, p$-adj=0.018), and puromycinsensitive aminopeptidase (PSA) $(F(1,130)=9.11$, $p$-adj=0.043). HSP90 and TE $\beta$ abundances were also significantly different between bays (respectively: $F(3,131)=7.80$, $p$-adj $=0.0011$; $F(3,345)=5.19$, $p$-adj=0.034), but these differences were driven by regional differences, as posthoc tests detected no differences between Case Inlet and Willapa Bay (southern), or beteen Fidalgo Bay and Port Gamble Bay (northern). For the three differentially abundant proteins, abundances were lowest in Case Inlet (southernmost in Puget Sound) followed by WIIlapa Bay (southernmost overall), then Port Gamble Bay, and highest in Fidalgo Bay (northernmost). 
bioRxiv preprint doi: https://doi.org/10.1101/432542; this version posted January 26, 2019. The copyright holder for this preprint (which was not certified by peer review) is the author/funder, who has granted bioRxiv a license to display the preprint in perpetuity. It is made available under aCC-BY-ND 4.0 International license.
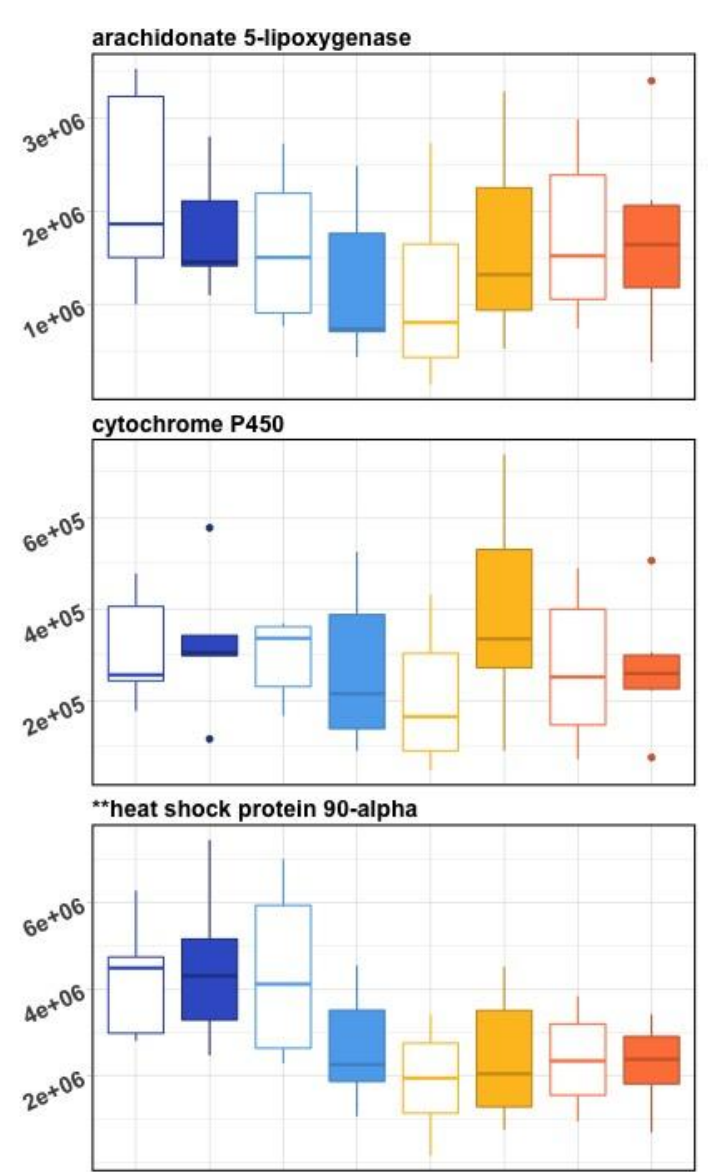

*puromycin-sensitive aminopeptidase
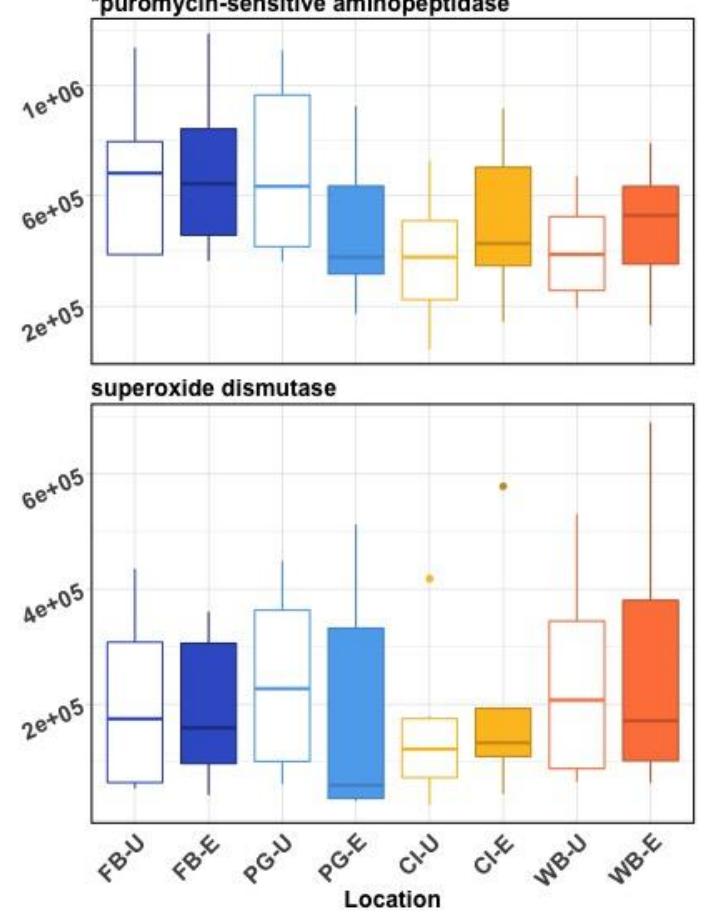

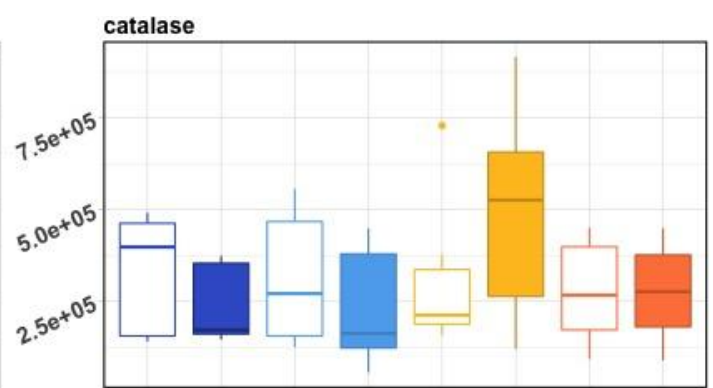

glycogen phosphorylase
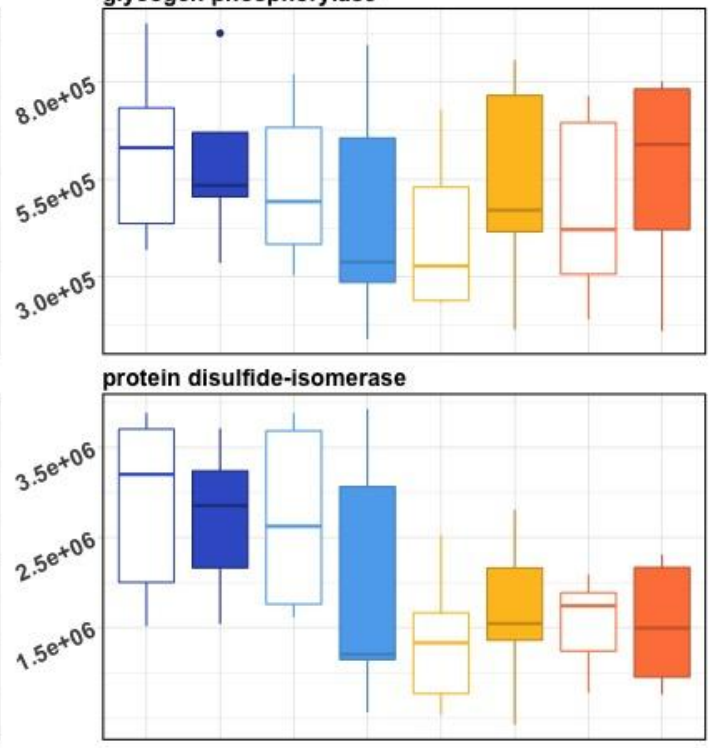

Na/K-transporting ATPase
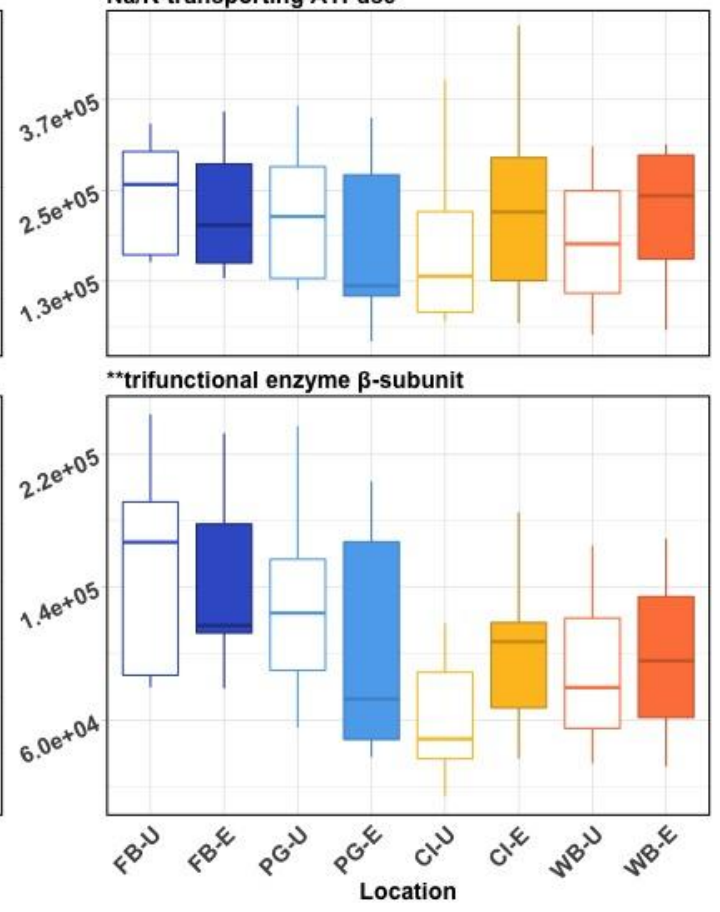
Figure 4: Boxplots of protein mean spectral abundances (mean of 2 or 3 peptides targeted for each protein) for Fidalgo Bay (FB), Port Gamble Bay (PG), Case Inlet (Cl), and Willapa Bay (WB), where -U and -E represent unvegetated (white boxes) and eelgrass (filled boxes) habitats, respectively. For each location, $n=5$ or 6 geoduck. Boxes contain all biological replicates lying within the interquartile range (IQR), with median abundances indicated by line in middle of boxes. Whiskers extend to the largest value no greater than $1.5^{\star} \mathrm{IQR}$, and dots indicate outliers beyond $1.5^{*} I Q R$. Protein abundance ranges ( $y$-axes) vary between proteins. Differentially abundant proteins between region and bay are indicated by $\left({ }^{* *}\right)$, and region only by $\left({ }^{*}\right)$. No protein abundances were significantly different between habitats.

430 Growth positively correlated with peptide abundance in all but 2 of the 10 targeted proteins (no correlation with catalase and superoxide dismutase), including the three proteins that were differentially abundant between bays (Table 3). Growth also correlated with most environmental parameters (excluding salinity SD). Heat Shock Protein 90 correlated positively with dissolved oxygen SD. Mean and SD pH did not correlate with any peptide abundance patterns or growth. None of the environmental parameters, nor growth, correlated significantly with peptide abundances pooled across all proteins.

\begin{tabular}{|c|c|c|c|c|}
\hline & Growth & $\begin{array}{c}\text { heat shock } \\
\text { protein } 90\end{array}$ & $\begin{array}{c}\text { puromycin } \\
\text { sensitive } \\
\text { aminopeptidase }\end{array}$ & $\begin{array}{c}\text { trifunctional } \\
\text { enzyme } \beta- \\
\text { subunit }\end{array}$ \\
\hline Growth & --- & $\begin{array}{c}r=0.53 \\
p=5.54 e-11\end{array}$ & $\begin{array}{c}r=0.46 \\
p=1.42 e-7\end{array}$ & $\begin{array}{c}r=0.43 \\
p=9.70 e-7\end{array}$ \\
\hline$T_{\text {mean }}$ & $\begin{array}{c}r=-0.39 \\
p=8.11 e-21\end{array}$ & $\begin{array}{l}r=-0.36 \\
p=0.060\end{array}$ & $\begin{array}{c}r=-0.24 \\
p=0.48\end{array}$ & $\begin{array}{c}r=-0.21 \\
p=0.70\end{array}$ \\
\hline $\mathbf{T}_{\mathbf{s d}}$ & $\begin{array}{c}r=0.39 \\
p=2.10 \mathrm{e}-20\end{array}$ & $\begin{array}{l}r=0.24 \\
p=0.42\end{array}$ & $\begin{array}{c}r=0.15 \\
p=1\end{array}$ & $\begin{array}{c}r=0.11 \\
p=1\end{array}$ \\
\hline $\mathrm{DO}_{\text {mean }}$ & $\begin{array}{c}r=0.45 \\
p=2.12 e-28\end{array}$ & $\begin{array}{l}r=0.26 \\
p=0.34\end{array}$ & $\begin{array}{l}r=0.18 \\
p=0.91\end{array}$ & $\begin{array}{l}r=0.21 \\
p=0.66\end{array}$ \\
\hline $\mathrm{DO}_{\mathrm{sd}}$ & $\begin{array}{c}r=0.48 \\
p=2.64 e-32\end{array}$ & $\begin{array}{c}r=0.41 \\
p=0.021\end{array}$ & $\begin{array}{l}r=0.31 \\
p=0.16\end{array}$ & $\begin{array}{l}r=0.31 \\
p=0.15\end{array}$ \\
\hline $\mathrm{pH}_{\text {mean }}$ & $\begin{array}{c}r=-0.32 \\
p=1.08 e-12\end{array}$ & $\begin{array}{c}r=-0.09 \\
p=1\end{array}$ & $\begin{array}{c}r=-0.02 \\
p=1\end{array}$ & $\begin{array}{c}r=-0.03 \\
p=1\end{array}$ \\
\hline $\mathrm{pH}_{\mathrm{sd}}$ & $\begin{array}{c}r=0.30 \\
p=8.72 e-11\end{array}$ & $\begin{array}{l}r=0.22 \\
p=0.73\end{array}$ & $\begin{array}{c}r=0.06 \\
p=1\end{array}$ & $\begin{array}{c}r=0.04 \\
p=1\end{array}$ \\
\hline
\end{tabular}

Table 3: Correlation analysis results between growth, environmental parameters, and peptide abundance (z-transformed). Correlation coefficient

$r$ shown with $p$-values adjusted via Bonferroni correction (number of comparisons). Correlations deemed significant are in bold. 


\section{Discussion}

This study tested the effects of varying $\mathrm{pH}$ on geoduck, a valuable aquaculture species in a natural setting, and confirmed that Zostera marina eelgrass can effectively alter local $\mathrm{pH}$ during warm summer months (June and July). We have shown that ocean acidification research on cultured shellfish can augment findings from controlled laboratory studies with field deployments to incorporate natural variability and relevant environmental drivers associated with an organism's habitat. Targeted proteomics was assessed alongside growth and environmental data for an integrated view of how geoduck respond to varying environmental conditions. Proteomics is a powerful approach suitable for comparative physiological studies of non-model, marine organisms (Tomanek, 2014). Using a two step method, this study detected substantially more proteins $(8,077)$ compared to the previous geoduck study using Data Dependent Acquisition (3,651) (Timmins-Schiffman et al. 2017). This produced a valuable protein catalogue for future projects, as researchers can now skip directly to the targeted SRM phase to greatly reduce the cost and time associated with a discovery analysis.

Geoduck exhibited no phenotypic differences between $\mathrm{pH}$ conditions, counter to our predictions. We predicted that $\mathrm{pH}$ would be higher within eelgrass habitats, creating a refuge against the less alkaline surrounding waters and reducing oxidative stress. Concordantly, proteins involved in the oxidative stress response would be less abundant inside eelgrass habitats (such as superoxide dismutase, peroxiredoxin-1, catalase, and HSP), possibly translating to differential growth as less energy would be used to counter the $\mathrm{pH}$ stress. While $\mathrm{pH}$ in eelgrass habitats was found to be consistently higher in this study, no differences in abundance of selected peptides, growth or survival were found between habitats across all four bays. This suggests that juvenile geoduck may tolerate a wide $\mathrm{pH}$ range in the context of the natural environment in which they are cultured.

Earlier studies on other clam species point to some degree of $\mathrm{pH}$ tolerance, but also describe complex responses to low $\mathrm{pH}$ that vary between metrics, species, and when secondary stressors are applied (Ries et al. 2009; Ringwood and Keppler 2002; G. G. Waldbusser et al. 2010). For example, juvenile carpet shell clams (Ruditapes decussatus) under ambient (pH 8.2) and reduced $\mathrm{pH}(7.8,7.5)$ for 75 days displayed no difference in size, weight, or calcification rate (Range et al. 2011), but other physiological parameters (clearance, ingestion, respiration, ammonia excretion) differed at day 87 (Fernández-Reiriz et al. 2011). In the hard clam Mercenaria mercenaria, protein oxidation, biomineralization, and standard metabolic rate (SMR, measured as resting oxygen consumption) in adults were largely unaffected by hypercapnia alone, but when combined with elevated temperature SMR increased and shell strength decreased (Ivanina et al. 2013; Matoo et al. 2013). Interestingly, the baltic clam (Macoma balthica) grew significantly larger in low pH (7.35 vs. 7.85 for 29 days), and were largest when combined with low dissolved oxygen ( $3.0 \mathrm{mg} / \mathrm{L}$ vs. $8.5 \mathrm{mg} / \mathrm{L})$ (Jansson et al. 2015). Geoduck metrics examined in this study were not affected by varying $\mathrm{pH}$, but other physiological parameters (metabolic rate, biomineralization, reproductive development, cytoskeleton), and other tissues such as mantle or hepatopancreas, may be affected and should be examined in future studies.

The complex, mixed responses exhibited in clam species may, in part, be a function of local adaptation to varying environmental drivers. Pacific geoduck are native to the Puget 
Sound, a region that experiences regular episodes of low $\mathrm{pH}$ in certain areas and has significant diel and monthly pH variability (Busch et al. 2013; Feely et al. 2008, 2010). Thus, the species may have evolved under selective pressure to withstand periods of low $\mathrm{pH}$. The native Northeast Pacific Coast oyster, Ostrea lurida, also shows signs of $\mathrm{pH}$ tolerance as veliger larvae compared to the non-native Pacific oyster (Crassostrea gigas) (Waldbusser et al. 2016), a stage primarily found to be vulnerable in other calcifying species (for reviews see Byrne and Przeslawski 2013; Kurihara 2008). Geoduck are also infaunal organisms, extending their long siphons into the water column for feeding and retreating to deep burrows during low tide or when disturbed (Goodwin and Pease 1987). Sediment and burrow chemistry, while influenced by the overlying water column, can have lower $\mathrm{pH}$ due to aerobic microbial activity, another potential source of selective pressure shaping this giant clam's pH tolerance (Gattuso and Hansson 2011; Widdicombe and Spicer 2008). An important future step is to assess the relative influence of sediment $\mathrm{pH}$ and overlying water column $\mathrm{pH}$ on burrowing calcifiers. This is particularly applicable when comparing habitats that likely have varying bacterial communities and activity.

While $\mathrm{pH}$ was not a universal predictor of geoduck phenotype in this study, mean temperature and dissolved oxygen variability correlated significantly with biometric parameters and separated into two groups: northern bays (Fidalgo and Port Gamble Bays), and southern bays (Case Inlet, and Willapa Bay). Geoduck grew less (or not at all, in Case Inlet) and had lower levels of targeted proteins in the southern bays, which were warmer with less variable dissolved oxygen content.

Temperatures in the southern bays $\left(16-18^{\circ} \mathrm{C}\right)$ during the deployment dates may have exceeded optimal conditions for juvenile geoduck, resulting in elevated metabolism and less energy available for growth (Newell and Branch 1980). Similar temperature-dependent growth was observed in $M$. mercenaria, where shell calcification rate was highest between $12.8-15.2^{\circ} \mathrm{C}$, above which growth negatively correlated with temperature (except for a secondary peak at $23.9^{\circ} \mathrm{C}$ ) (Storr et al. 1982). In P. generosa, Goodwin (1973) reported that temperature for normal larval development is between $6-16^{\circ} \mathrm{C}$. In adults, the optimal hatchery temperature for reproduction is relatively low (appr. $\left.11^{\circ} \mathrm{C}\right)$, and at the highest experimental temperature $\left(19^{\circ} \mathrm{C}\right)$ gonad did not regenerate after an initial spawning event (Marshall et al. 2012). Arney et al. (2015) found that in early juveniles $(<3.5 \mathrm{~mm})$, growth increased with temperature within $7-19^{\circ} \mathrm{C}$ when fed ad libitum. However, organic weight accumulation (total body ash-free dry weight) was highest between $11-15^{\circ} \mathrm{C}$, indicating that the optimal juvenile temperature may be approximately $15^{\circ} \mathrm{C}$. In the present study, geoduck grew fastest in cooler, northern bays $\left(15^{\circ} \mathrm{C}\right)$, but stress protein abundances (e.g. HSP90) did not suggest an acute thermal stress in the warmer, southern bays (abundances were inversely related to temperature). Southern bays may have exceeded the geoduck upper pejus temperature but remained below acute-stress, which could explain the reduced growth in those locations without a proteomic signal. Conversely, as tissues were collected at day 30 , a heat stress signal could have been captured with earlier or more frequent samples. A thermal performance curve for $P$. generosa under natural feeding levels would be valuable for aquaculture siting, but these data suggest that cooler summer temperatures are more suitable for culturing geoduck.

Dissolved oxygen (DO) variability may be an indirect indicator of geoduck performance as it is often correlated to phytoplankton biomass (Khangaonkar et al. 2012). Less DO 
fluctuation in the southern bays could be an indicator of less phytoplankton biomass, translating to lower food availability (Anderson and Taylor 2001; Bergondo et al. 2005; Winter et al. 1975). While we were unable to monitor chlorophyll during the outplant, both southern bays, Willapa Bay and Case Inlet, may have phytoplankton populations that are controlled by shellfish grazers due to long residence times and aquaculture activity (Banas et al. 2007; Washington Sea Grant 2015). It is possible that food availability was different between northern and southern locations during the outplant period (June-July), and could be the underlying cause of higher growth and abundances of selected proteins in the northern locations (Carmichael, Shriver, and Valiela 2004; Liu et al. 2016; Loosanoff and Davis 1963), although this warrants additional data collection.

\section{Conclusion}

537 This is the first study to investigate geoduck performance alongside varying $\mathrm{pH}$ conditions, and contributes a geoduck ctenidia peptide database useful for quantifying multiple proteins simultaneously. The primary finding is that geoduck aquaculture may be less impacted by ocean acidification compared to other environmental stressors, for example ocean warming. Geoduck ocean acidification research is in its infancy, and these results are a snapshot into geoduck physiology at one developmental stage, using one tissue type (ctenidia), with individuals from one genetic pool, and with present-day $\mathrm{pH}$ levels in Washington State. To best inform current and future geoduck aquaculture, further foundational studies are needed to elucidate the variability in the species' $\mathrm{pH}$ limits in conjunction with more acute environmental stressors, and expanded to include other key tissues and functions (e.g. mantle for shell secretion), and wholeanimal physiological studies (e.g. metabolic rate, reproductive development).

This study also demonstrates applied use of systems such as eelgrass beds in estuaries to test $\mathrm{pH}$ effects in a natural system. There is growing interest in using macroalgae as an ocean acidification bioremediation tool, also known as phytoremediation (Greiner et al. 2013; Hendriks et al. 2014; Washington State Blue Ribbon Panel on Ocean Acidification 2012; Groner et al. 2018). Incorporating seagrass into shellfish-pH interaction studies can help evaluate the potential for merging mariculture with shellfish aquaculture to improve growing conditions for vulnerable cultured species.

\section{Acknowledgements}

556 Our gratitude to the following people who assisted with this project: Grace Crandall, Kaitlyn

557 Mitchell and Jose Guzman assisted with protein extraction. Jarrett Egertson contributed to DIA 558 design. Austin Keller adapted MSConvert to correctly demultiplex and convert DIA files. Han-Yin 559 Yang, Brian Searle and Sean Bennett assisted with running PECAN. Brittany Taylor and Taylor 560 Shellfish Farms provided geoducks. Thank you to anonymous reviewers for the helpful 561 feedback. 
This work was supported in part by the National Science Foundation Graduate Research Fellowship Program, the NOAA Ocean Acidification Program, the University of Washington's Proteomics Resource (UWPR95794), and the Washington Department of Natural Resources.

\section{Reference List}

568

569

570

571

572

573

574

575

576

577

578

579

580

581

582

583

584

585

586

587

588

589

590

591

592

593

594

595

596

597

598

599

600

601

602

603

604

605

606

607

608

609

610

Abatzoglou, John T., David E. Rupp, and Philip W. Mote. 2013. "Seasonal Climate Variability and Change in the Pacific Northwest of the United States." Journal of Climate 27 (5): 212542.

Anderson, Timothy H., and Gordon T. Taylor. 2001. "Nutrient Pulses, Plankton Blooms, and Seasonal Hypoxia in Western Long Island Sound." Estuaries 24 (2): 228-43.

Apweiler, Rolf, Amos Bairoch, Cathy H. Wu, Winona C. Barker, Brigitte Boeckmann, Serenella Ferro, Elisabeth Gasteiger, et al. 2004. "UniProt: The Universal Protein Knowledgebase." Nucleic Acids Research 32 (Database issue): D115-19.

Arney, Bianca, Wenshan Liu, lan Forster, R. Scott Mckinley, and Christopher M. Pearce. 2015. "Temperature and Food-Ration Optimization in the Hatchery Culture of Juveniles of the Pacific Geoduck Panopea Generosa." Journal of Shellfish Research 34 (1): 39-54.

Banas, N. S., B. M. Hickey, P. MacCready, and J. A. Newton. 2004. "Dynamics of Willapa Bay, Washington: A Highly Unsteady, Partially Mixed Estuary." Journal of Physical Oceanography 34 (11): 2413-27.

Banas, N. S., B. M. Hickey, J. A. Newton, and J. L. Ruesink. 2007. "Tidal Exchange, Bivalve Grazing, and Patterns of Primary Production in Willapa Bay, Washington, USA." Marine Ecology Progress Series 341: 123-39.

Bergondo, Deanna L., Dana R. Kester, Heather E. Stoffel, and Wendy L. Woods. 2005. "TimeSeries Observations during the Low Sub-Surface Oxygen Events in Narragansett Bay during Summer 2001." Marine Chemistry 97 (1): 90-103.

Box, G. E. P., and D. R. Cox. 1964. "An Analysis of Transformations." Journal of the Royal Statistical Society. Series B, Statistical Methodology 26 (2): 211-52. Boyd, Philip W., Christopher E. Cornwall, Andrew Davison, Scott C. Doney, Marion Fourquez, Catriona L. Hurd, Ivan D. Lima, and Andrew McMinn. 2016. "Biological Responses to Environmental Heterogeneity under Future Ocean Conditions." Global Change Biology 22 (8): 2633-50.

Bozaykut, Perinur, Nesrin Kartal Ozer, and Betul Karademir. 2014. "Regulation of Protein Turnover by Heat Shock Proteins." Free Radical Biology \& Medicine 77 (December): 195209.

Bulthuis, Douglas A. 1995. "Distribution of Seagrasses in a North Puget Sound Estuary: Padilla Bay, Washington, USA." Aquatic Botany 50 (1): 99-105.

Busch, D. Shallin, Chris J. Harvey, and Paul McElhany. 2013. "Potential Impacts of Ocean Acidification on the Puget Sound Food Web." ICES Journal of Marine Science: Journal Du Conseil 70 (4): 823-33.

Byrne, Maria, and Rachel Przeslawski. 2013. "Multistressor Impacts of Warming and Acidification of the Ocean on Marine Invertebrates' Life Histories." Integrative and Comparative Biology 53 (4): 582-96.

Carmichael, R. H., Andrea C. Shriver, and I. Valiela. 2004. "Changes in Shell and Soft Tissue Growth, Tissue Composition, and Survival of Quahogs, Mercenaria Mercenaria, and Softshell Clams, Mya Arenaria, in Response to Eutrophic-Driven Changes in Food Supply and Habitat." Journal of Experimental Marine Biology and Ecology 313 (1): 75-104.

Chambers, Matthew C., Brendan Maclean, Robert Burke, Dario Amodei, Daniel L. Ruderman, Steffen Neumann, Laurent Gatto, et al. 2012. "A Cross-Platform Toolkit for Mass 
611

612

613

614

615

616

617

618

619

620

621

622

623

624

625

626

627

628

629

630

631

632

633

634

635

636

637

638

639

640

641

642

643

644

645

646

647

648

649

650

651

652

653

654

655

656

657

658

659

660

Spectrometry and Proteomics." Nature Biotechnology 30 (10): 918-20.

Coan, Eugene V., Paul Valentich Scott, and Frank R. Bernard. 2000. Bivalve Seashells of Western North America: Marine Bivalve Mollusks from Arctic Alaska to Baja California. Santa Barbara Museum of Natural History.

Dethier, Megan N., Tom Mumford, Tom Leschine, Kurt Presh, Si Simenstad, Hugh Shipman, Doug Myers, et al. 2006. "Native Shellfish in Nearshore Ecosystems of Puget Sound." WASHINGTON UNIV SEATTLE. http://www.dtic.mil/docs/citations/ADA477852.

Doney, Scott C., Natalie Mahowald, Ivan Lima, Richard A. Feely, Fred T. Mackenzie, JeanFrancois Lamarque, and Phil J. Rasch. 2007. "Impact of Anthropogenic Atmospheric Nitrogen and Sulfur Deposition on Ocean Acidification and the Inorganic Carbon System." Proceedings of the National Academy of Sciences of the United States of America 104 (37): 14580-85.

Duquette, Ashley, James B. McClintock, Charles D. Amsler, Alberto Pérez-Huerta, Marco Milazzo, and Jason M. Hall-Spencer. 2017. "Effects of Ocean Acidification on the Shells of Four Mediterranean Gastropod Species near a CO2 Seep." Marine Pollution Bulletin 124 (2): 917-28.

Fabbri, E., P. Valbonesi, and S. Franzellitti. 2008. "HSP Expression in Bivalves." Invertebrate Survival Journal: ISJ 5 (135): e161.

Feely, Richard A., Simone R. Alin, Jan Newton, Christopher L. Sabine, Mark Warner, Allan Devol, Christopher Krembs, and Carol Maloy. 2010. "The Combined Effects of Ocean Acidification, Mixing, and Respiration on $\mathrm{pH}$ and Carbonate Saturation in an Urbanized Estuary." Estuarine, Coastal and Shelf Science 88 (4): 442-49.

Feely, Richard A., Terrie Klinger, Jan A. Newton, and Meg Chadsey. 2012. Scientific Summary of Ocean Acidification in Washington State Marine Waters. US Department of Commerce, National Oceanic and Atmospheric Administration, Office of Oceanic and Atmospheric Research.

Feely, Richard A., Christopher L. Sabine, J. Martin Hernandez-Ayon, Debby lanson, and Burke Hales. 2008. "Evidence for Upwelling of Corrosive' Acidified' Water onto the Continental Shelf." Science 320 (5882): 1490-92.

Fernández-Reiriz, Ma José, Pedro Range, Xosé Antón Álvarez-Salgado, and Uxio Labarta. 2011. "Physiological Energetics of Juvenile Clams Ruditapes Decussatus in a High $\mathrm{CO}_{2}$ Coastal Ocean." Marine Ecology Progress Series 433: 97-105.

Gattuso, Jean-Pierre, and Lina Hansson. 2011. Ocean Acidification. OUP Oxford.

Gazeau, Frédéric, Christophe Quiblier, Jeroen M. Jansen, Jean-Pierre Gattuso, Jack J. Middelburg, and Carlo H. R. Heip. 2007. "Impact of Elevated CO2 on Shellfish Calcification." Geophysical Research Letters 34 (7): L07603.

Giarratano, Erica, Mónica N. Gil, and Gabriela Malanga. 2014. "Biomarkers of Environmental Stress in Gills of Ribbed Mussel Aulacomya Atra Atra (Nuevo Gulf, Northern Patagonia)." Ecotoxicology and Environmental Safety 107 (September): 111-19.

Gobler, Christopher J., Elizabeth L. DePasquale, Andrew W. Griffith, and Hannes Baumann. 2014. "Hypoxia and Acidification Have Additive and Synergistic Negative Effects on the Growth, Survival, and Metamorphosis of Early Life Stage Bivalves." PloS One 9 (1): e83648.

Goodwin, C. L. 1973. "Effects of Salinity and Temperature on Embryos of the Geoduck Clam (Panope generosa Gould)." In Proceedings of the National Shellfisheries Association, 63:93-95.

Goodwin, C. Lynn, and Bruce Pease. 1987. The Distribution of Geoduck (Panope Abrupta) Size, Density, and Quality in Relation to Habitat Characteristics such as Geographic Area, Water Depth, Sediment Type, and Associated Flora and Fauna in Puget Sound, Washington. State of Washington, Department of Fisheries, Shellfish Division. 
661

662

663

664

665

666

667

668

669

670

671

672

673

674

675

676

677

678

679

680

681

682

683

684

685

686

687

688

689

690

691

692

693

694

695

696

697

698

699

700

701

702

703

704

705

706

707

708

709

710

Greiner, Jill T., Karen J. McGlathery, John Gunnell, and Brent A. McKee. 2013. "Seagrass Restoration Enhances 'Blue Carbon' Sequestration in Coastal Waters.” PloS One 8 (8): e72469.

Groner, Maya L., Colleen A. Burge, Ruth Cox, Natalie Rivlin, Mo Turner, Kathryn L. Van Alstyne, Sandy Wyllie-Echeverria, John Bucci, Philip Staudigel, and Carolyn S. Friedman. 2018. "Oysters and Eelgrass: Potential Partners in a High pCO2 Ocean." Ecology, May. https://doi.org/10.1002/ecy.2393.

Harvey, Ben P., Dylan Gwynn-Jones, and Pippa J. Moore. 2013. "Meta-Analysis Reveals Complex Marine Biological Responses to the Interactive Effects of Ocean Acidification and Warming." Ecology and Evolution 3 (4): 1016-30.

Hendriks, Iris E., Y. S. Olsen, L. Ramajo, L. Basso, A. Steckbauer, T. S. Moore, J. Howard, and C. M. Duarte. 2014. "Photosynthetic Activity Buffers Ocean Acidification in Seagrass Meadows." Biogeosciences 11 (2): 333.

Howarth, Robert, Francis Chan, Daniel J. Conley, Josette Garnier, Scott C. Doney, Roxanne Marino, and Gilles Billen. 2011. "Coupled Biogeochemical Cycles: Eutrophication and Hypoxia in Temperate Estuaries and Coastal Marine Ecosystems." Frontiers in Ecology and the Environment 9 (1): 18-26.

$\mathrm{Hu}$, Menghong, Lisha Li, Yanming Sui, Jiale Li, Youji Wang, Weiqun Lu, and Sam Dupont. 2015. "Effect of pH and Temperature on Antioxidant Responses of the Thick Shell Mussel Mytilus Coruscus." Fish \& Shellfish Immunology 46 (2): 573-83.

Ivanina, Anna V., Gary H. Dickinson, Omera B. Matoo, Rita Bagwe, Ashley Dickinson, Elia Beniash, and Inna M. Sokolova. 2013. "Interactive Effects of Elevated Temperature and CO2 Levels on Energy Metabolism and Biomineralization of Marine Bivalves Crassostrea Virginica and Mercenaria Mercenaria." Comparative Biochemistry and Physiology. Part A, Molecular \& Integrative Physiology 166 (1): 101-11.

Jansson, Anna, Joanna Norkko, Sam Dupont, and Alf Norkko. 2015. "Growth and Survival in a Changing Environment: Combined Effects of Moderate Hypoxia and Low pH on Juvenile Bivalve Macoma Balthica." Journal of Sea Research 102 (August): 41-47.

Kerrison, Philip, Jason M. Hall-Spencer, David J. Suggett, Leanne J. Hepburn, and Michael Steinke. 2011. "Assessment of $\mathrm{pH}$ Variability at a Coastal CO2 Vent for Ocean Acidification Studies." Estuarine, Coastal and Shelf Science 94 (2): 129-37.

Khangaonkar, Tarang, Brandon Sackmann, Wen Long, Teizeen Mohamedali, and Mindy Roberts. 2012. "Simulation of Annual Biogeochemical Cycles of Nutrient Balance, Phytoplankton Bloom(s), and DO in Puget Sound Using an Unstructured Grid Model." Ocean Dynamics 62 (9): 1353-79.

Kroeker, Kristy J., Rebecca L. Kordas, Ryan N. Crim, and Gerald G. Singh. 2010. "MetaAnalysis Reveals Negative yet Variable Effects of Ocean Acidification on Marine Organisms." Ecology Letters 13 (11): 1419-34.

Kurihara, H. 2008. "Effects of CO2-Driven Ocean Acidification on the Early Developmental Stages of Invertebrates." Marine Ecology Progress Series 373 (December): 275-84.

Liu, W., C. M. Pearce, R. S. McKinley, and I. P. Forster. 2016. "Nutritional Value of Selected Species of Microalgae for Larvae and Early Post-Set Juveniles of the Pacific Geoduck Clam, Panopea Generosa." Aquaculture 452 (Supplement C): 326-41.

Loosanoff, Victor L., and Harry C. Davis. 1963. "Rearing of Bivalve Mollusks." In Advances in Marine Biology, edited by F. S. Russell, 1:1-136. Academic Press.

Lushchak, Volodymyr I. 2011. "Environmentally Induced Oxidative Stress in Aquatic Animals." Aquatic Toxicology 101 (1): 13-30.

MacLean, Brendan, Daniela M. Tomazela, Nicholas Shulman, Matthew Chambers, Gregory L. Finney, Barbara Frewen, Randall Kern, David L. Tabb, Daniel C. Liebler, and Michael J. MacCoss. 2010. "Skyline: An Open Source Document Editor for Creating and Analyzing 
711

712

713

714

715

716

717

718

719

720

721

722

723

724

725

726

727

728

729

730

731

732

733

734

735

736

737

738

739

740

741

742

743

744

745

746

747

748

749

750

751

752

753

754

755

756

757

758

759

760

Targeted Proteomics Experiments." Bioinformatics 26 (7): 966-68.

Marshall, Robert, R. Scott McKinley, and Christopher M. Pearce. 2012. "Effect of Temperature on Gonad Development of the Pacific Geoduck Clam (Panopea Generosa Gould, 1850)." Aquaculture 338-341 (March): 264-73.

Matoo, Omera B., Anna V. Ivanina, Claus Ullstad, Elia Beniash, and Inna M. Sokolova. 2013. "Interactive Effects of Elevated Temperature and CO2 Levels on Metabolism and Oxidative Stress in Two Common Marine Bivalves (Crassostrea Virginica and Mercenaria Mercenaria)." Comparative Biochemistry and Physiology. Part A, Molecular \& Integrative Physiology 164 (4): 545-53.

Matozzo, Valerio, Andrea Chinellato, Marco Munari, Monica Bressan, and Maria Gabriella Marin. 2013. "Can the Combination of Decreased pH and Increased Temperature Values Induce Oxidative Stress in the Clam Chamelea Gallina and the Mussel Mytilus Galloprovincialis?" Marine Pollution Bulletin 72 (1): 34-40.

Middelboe, Anne Lise, and Per Juel Hansen. 2007. "High pH in Shallow-Water Macroalgal Habitats." Marine Ecology Progress Series 338: 107-17.

Miller, A. Whitman, Amanda C. Reynolds, Cristina Sobrino, and Gerhardt F. Riedel. 2009. "Shellfish Face Uncertain Future in High CO2 World: Influence of Acidification on Oyster Larvae Calcification and Growth in Estuaries." PloS One 4 (5): e5661.

Moore, Stephanie K., Nathan J. Mantua, Jan A. Newton, Mitsuhiro Kawase, Mark J. Warner, and Jonathan P. Kellogg. 2008. "A Descriptive Analysis of Temporal and Spatial Patterns of Variability in Puget Sound Oceanographic Properties." Estuarine, Coastal and Shelf Science 80 (4): 545-54.

Mote, Philip W., and Eric P. Salathé. 2010. "Future Climate in the Pacific Northwest." Climatic Change 102 (1-2): 29-50.

Newell, R. C., and G. M. Branch. 1980. "The Influence of Temperature on the Maintenance of Metabolic Energy Balance in Marine Invertebrates." In Advances in Marine Biology, edited by J. H. S. Blaxter, Frederick S. Russell, and Maurice Yonge, 17:329-96. Academic Press.

Oksanen, J., F. Guillaume Blanchet, M. Friendly, R. Kindt, P. Legendre, D. McGlinn, P. R. Minchin, et al. 2016. Vegan: Community Ecology Package (version R package version 2.41, 2016). https:// CRAN.R-project.org/package=vegan.

Orr, James C., Victoria J. Fabry, Olivier Aumont, Laurent Bopp, Scott C. Doney, Richard A. Feely, Anand Gnanadesikan, et al. 2005. "Anthropogenic Ocean Acidification over the Twenty-First Century and Its Impact on Calcifying Organisms." Nature 437 (September): 681.

Paganini, Adam W., Nathan A. Miller, and Jonathon H. Stillman. 2014. "Temperature and Acidification Variability Reduce Physiological Performance in the Intertidal Zone Porcelain Crab Petrolisthes Cinctipes." The Journal of Experimental Biology 217 (22): 3974-80.

Palacios, Sherry L., and Richard C. Zimmerman. 2007. "Response of Eelgrass Zostera Marina to $\mathrm{CO}^{2}$ Enrichment: Possible Impacts of Climate Change and Potential for Remediation of Coastal Habitats." Marine Ecology Progress Series 344: 1-13.

Pörtner, Hans-O. 2008. "Ecosystem Effects of Ocean Acidification in Times of Ocean Warming: A Physiologist's View." Marine Ecology Progress Series 373: 203-18.

Pörtner, Hans O., and Anthony P. Farrell. 2008. "Physiology and Climate Change." Science 322 (5902): 690-92.

Przeslawski, Rachel, Maria Byrne, and Camille Mellin. 2015. "A Review and Meta-Analysis of the Effects of Multiple Abiotic Stressors on Marine Embryos and Larvae." Global Change Biology 21 (6): 2122-40.

Range, P., M. A. Chícharo, R. Ben-Hamadou, D. Piló, D. Matias, S. Joaquim, A. P. Oliveira, and L. Chícharo. 2011. "Calcification, Growth and Mortality of Juvenile Clams Ruditapes Decussatus under Increased pCO2 and Reduced pH: Variable Responses to Ocean 
761

762

763

764

765

766

767

768

769

770

771

772

773

774

775

776

777

778

779

780

781

782

783

784

785

786

787

788

789

790

791

792

793

794

795

796

797

798

799

800

801

802

803

804

805

806

807

808

809

810

Acidification at Local Scales?" Journal of Experimental Marine Biology and Ecology 396 (2): 177-84.

R Core Team. 2016. R: A Language and Environment for Statistical Computing (version 1.1.383). https://www.R-project.org/.

Ries, Justin B., Anne L. Cohen, and Daniel C. McCorkle. 2009. "Marine Calcifiers Exhibit Mixed Responses to CO2-Induced Ocean Acidification." Geology 37 (12): 1131-34.

Ringwood, Amy H., and Charles J. Keppler. 2002. "Water Quality Variation and Clam Growth: Is pH Really a Non-Issue in Estuaries?" Estuaries 25 (5): 901-7.

Shamshak, Gina Louise, and Jonathan R. King. 2015. "From Cannery to Culinary Luxury: The Evolution of the Global Geoduck Market." Marine Policy 55 (May): 81-89.

Spencer, Laura H., Yaamini Venkataraman, Emma Timmins-Schiffman, Brook L. Nunn, Steven

B. Roberts, Micah Horwith, and Alexander T. Lowe. 2019. "Github Repo for "pacific Geoduck (panopea Generosa) Resilience to Natural Ph Variation"”. figshare. doi:10.6084/m9.figshare.7562354.v1.

Storr, John F., Alexander L. Costa, and David A. Prawel. 1982. "Effects of Temperature on Calcium Deposition in the Hard-Shell Clam, Mercenaria Mercenaria." Journal of Thermal Biology 7 (1): 57-61.

Thompson, E. L., W. O'Connor, L. Parker, P. Ross, and D. A. Raftos. 2015. "Differential Proteomic Responses of Selectively Bred and Wild-Type Sydney Rock Oyster Populations Exposed to Elevated CO2." Molecular Ecology 24 (6): 1248-62.

Thomsen, Jörn, Isabel Casties, Christian Pansch, Arne Körtzinger, and Frank Melzner. 2013. "Food Availability Outweighs Ocean Acidification Effects in Juvenile Mytilus Edulis:

Laboratory and Field Experiments." Global Change Biology 19 (4): 1017-27.

Timmins-Schiffman, Emma, William D. Coffey, Wilber Hua, Brook L. Nunn, Gary H. Dickinson, and Steven B. Roberts. 2014. "Shotgun Proteomics Reveals Physiological Response to Ocean Acidification in Crassostrea Gigas." BMC Genomics 15 (November): 951.

Timmins-Schiffman, Emma B., Grace A. Crandall, Brent Vadopalas, Michael E. Riffle, Brook L. Nunn, and Steven B. Roberts. 2017. "Integrating Discovery-Driven Proteomics and Selected Reaction Monitoring To Develop a Noninvasive Assay for Geoduck Reproductive Maturation." Journal of Proteome Research 16 (9): 3298-3309.

Ting, Ying Sonia. 2017. "Shifting the Paradigm: Peptide-Centric Analysis of Systematically Sampled Mass Spectrometry Data."

https://digital.lib.washington.edu/researchworks/bitstream/handle/1773/38147/Ting_washin gton_0250E_16676.pdf?sequence=1\&isAllowed=y.

Tomanek, Lars. 2011. "Environmental Proteomics: Changes in the Proteome of Marine Organisms in Response to Environmental Stress, Pollutants, Infection, Symbiosis, and Development." Annual Review of Marine Science 3: 373-99.

Tomanek, Lars, Marcus J. Zuzow, Anna V. Ivanina, Elia Beniash, and Inna M. Sokolova. 2011. "Proteomic Response to Elevated PCO2 Level in Eastern Oysters, Crassostrea Virginica: Evidence for Oxidative Stress." The Journal of Experimental Biology 214 (Pt 11): 1836-44.

Tomanek, Lars. 2014. "Proteomics to Study Adaptations in Marine Organisms to Environmental Stress." Journal of Proteomics 105 (Supplement C): 92-106.

Tomanek, Lars. 2015. "Proteomic Responses to Environmentally Induced Oxidative Stress." The Journal of Experimental Biology 218 (Pt 12): 1867-79.

Tukey, John W. 1977. "Exploratory Data Analysis." https://pdfs.semanticscholar.org/2f40/fd06bc9fd00a27437e14ed171e96e4fd9326.pdf.

Tunnicliffe, Verena, Kimberley T. A. Davies, David A. Butterfield, Robert W. Embley, Jonathan M. Rose, and William W. Chadwick Jr. 2009. "Survival of Mussels in Extremely Acidic Waters on a Submarine Volcano.” Nature Geoscience 2 (April): 344. 
811

812

813

814

815

816

817

818

819

820

821

822

823

824

825

826

827

828

829

830

831

832

833

834

835

836

837

838

839

840

841

842

843

844

845

846

847

848

849

850

851

852

853

854

855

856

857

858

859

860

Vadopalas, B., T. W. Pietsch, C. S. Friedman - Malacologia, and 2010. 2010. “... Proper Name for the Geoduck: Resurrection of Panopea Generosa Gould, 1850, from the Synonymy of Panopea Abrupta (Conrad, 1849)(Bivalvia: Myoida: Hiatellidae)." BioOne. http://www.bioone.org/doi/abs/10.4002/040.052.0111.

Vadopalas, Brent, Jonathan P. Davis, and Carolyn S. Friedman. 2015. "Maturation, Spawning, and Fecundity of the Farmed Pacific Geoduck Panopea Generosa in Puget Sound, Washington." Journal of Shellfish Research 34 (1): 31-37.

Wahl, M., S. Schneider Covachã, V. Saderne, C. Hiebenthal, J. D. Müller, C. Pansch, and Y. Sawall. 2018. "Macroalgae May Mitigate Ocean Acidification Effects on Mussel Calcification by Increasing pH and Its Fluctuations: Biogenic Fluctuations Mitigate OA Effects." Limnology and Oceanography 63 (1): 3-21.

Waldbusser, George G., Matthew W. Gray, Burke Hales, Chris J. Langdon, Brian A. Haley, Iria Gimenez, Stephanie R. Smith, Elizabeth L. Brunner, and Greg Hutchinson. 2016. "Slow Shell Building, a Possible Trait for Resistance to the Effects of Acute Ocean Acidification." Limnology and Oceanography 61 (6): 1969-83.

Waldbusser, G. G., H. Bergschneider, and M. A. Green. 2010. "Size-Dependent pH Effect on Calcification in Post-Larval Hard Clam Mercenaria Spp." Marine Ecology Progress Series 417 (November): 171-82.

Washington Sea Grant. 2013. "Final Report: Geoduck Aquaculture Research Program." Report to the Washington State Legislature. Washington Sea Grant Technical Report WSG-TR, 13-03.

Washington Sea Grant. 2015. "Shellfish Aquaculture in Washington State." Final Report to the Washington State Legislature 84. https://pdfs.semanticscholar.org/b833/e0fcb8a0459697f94fd86b9848ee0e59c0a2.pdf.

Washington State Blue Ribbon Panel on Ocean Acidification. 2012. "Ocean Acidification: From Knowledge to Action, Washington State's Strategic Response." 12-01-015 . Washington Department of Ecology, Olympia, Washington. https://fortress.wa.gov/ecy/publications/documents/1201015.pdf.

"Washington's Wild Geoduck Fishery | WA - DNR." n.d. Accessed November 20, 2017. https://www.dnr.wa.gov/programs-and-services/aquatics/shellfish/washingtons-wildgeoduck-fishery.

Watson, Sue-Ann, Southgate, Paul C., Miller, Gabrielle M., Moorhead, Jonathan A., and Knauer, Jens. 2012. "Ocean acidification and warming reduce juvenile survival of the fluted giant clam, Tridacna squamosa." Molluscan Research, 32 (3). pp. 177-180.

Weiss, Ingrid Maria, Noreen Tuross, Lia Addadi, and Steve Weiner. 2002. "Mollusc Larval Shell Formation: Amorphous Calcium Carbonate Is a Precursor Phase for Aragonite." The Journal of Experimental Zoology 293 (5): 478-91.

Wickham, Hadley. 2017. "ggplot2 - Elegant Graphics for Data Analysis (2nd Edition)." Journal of Statistical Software, Book Reviews 77 (2): 1-3.

Widdicombe, Stephen, and John I. Spicer. 2008. "Predicting the Impact of Ocean Acidification on Benthic Biodiversity: What Can Animal Physiology Tell Us?" Journal of Experimental Marine Biology and Ecology 366 (1): 187-97.

Winter, D. F., K. Banse, and G. C. Anderson. 1975. "The Dynamics of Phytoplankton Blooms in Puget Sound a Fjord in the Northwestern United States." Marine Biology 29 (2): 139-76.

"WWW Tide/Current Predictor - Site Selection." n.d. Accessed December 7, 2017. http://tbone.biol.sc.edu/tide/.

Zhang, Yang, Jin Sun, Huawei Mu, Jun Li, Yuehuan Zhang, Fengjiao Xu, Zhiming Xiang, Pei-Yuan Qian, Jian-Wen Qiu, and Ziniu Yu. 2015. "Proteomic Basis of Stress Responses in the Gills of the Pacific Oyster Crassostrea Gigas." Journal of Proteome Research 14 (1): $304-17$. 


\section{Supplemental Material}

\begin{tabular}{|c|c|c|c|c|c|c|c|c|c|c|c|}
\hline \multicolumn{12}{|c|}{ 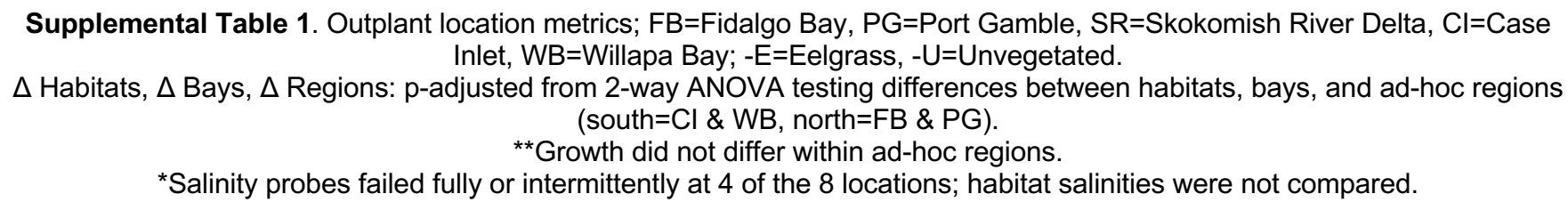 } \\
\hline $\begin{array}{l}\text { Deployment } \\
\text { location }\end{array}$ & FB-E & FB-U & PG-E & PG-U & Cl-E & Cl-U & WB-E & WB-U & ${ }_{\text {Habitat }}$ & $\begin{array}{l}\Delta \\
\text { Bays }\end{array}$ & $\begin{array}{l}\Delta \\
\text { Regions }\end{array}$ \\
\hline$\%$ Survival & 87 & 80 & 80 & 93 & 67 & 60 & 93 & 100 & $p=0.88$ & $p=0.25$ & $p=0.66$ \\
\hline $\begin{array}{r}\text { Mean Relative } \\
\% \text { Growth ( } \pm \\
\text { SD) }\end{array}$ & $\begin{array}{c}16.2 \\
( \pm 7.3)\end{array}$ & $\begin{array}{c}23.3 \\
( \pm 12.5)\end{array}$ & $\begin{array}{c}22.2 \\
( \pm 12.5)\end{array}$ & $\begin{array}{c}21.1 \\
( \pm 13.3)\end{array}$ & $\begin{array}{c}1.2 \\
( \pm 8.3)\end{array}$ & $\begin{array}{c}-2.8 \\
( \pm 5.3)\end{array}$ & $\begin{array}{c}10 \\
( \pm 16.2)\end{array}$ & $\begin{array}{c}4.5 \\
( \pm 8.3)\end{array}$ & $p=1$ & $\begin{array}{c}{ }^{* *} \mathrm{p}= \\
2.4 \mathrm{e}-10\end{array}$ & $\begin{array}{c}p= \\
4.9 \mathrm{e}-11\end{array}$ \\
\hline $\begin{array}{r}\text { Mean pH } \\
\text { (TS) }\end{array}$ & 7.90 & 7.54 & failed & 7.32 & 7.87 & 7.63 & 7.81 & 7.55 & $\begin{array}{c}p= \\
1.1 e-28\end{array}$ & $\begin{array}{c}p= \\
1.1 e-27\end{array}$ & $\begin{array}{c}p= \\
3.9 e-3\end{array}$ \\
\hline $\begin{array}{r}\text { pH Standard } \\
\text { Deviation (TS) }\end{array}$ & 0.19 & 0.23 & failed & 0.25 & 0.16 & 0.20 & 0.06 & 0.18 & $p=1$ & $\begin{array}{c}p= \\
1.0 e-20\end{array}$ & $\begin{array}{c}p= \\
1.6 e-15\end{array}$ \\
\hline $\begin{array}{r}\text { Mean DO } \\
(\mathrm{mg} / \mathrm{L})\end{array}$ & failed & 10.9 & 10.8 & 11.9 & 10.4 & 8.3 & 8.4 & 8.8 & $p=1$ & $\begin{array}{c}p= \\
1.1 e-25\end{array}$ & $\begin{array}{c}p= \\
3.2 e-19\end{array}$ \\
\hline $\begin{array}{r}\text { DO Standard } \\
\text { Deviation } \\
(\mathrm{mg} / \mathrm{L})\end{array}$ & failed & 5.7 & 3.9 & 3.9 & 2.6 & 1.9 & 1.5 & 1.3 & $p=0.31$ & $\begin{array}{c}p= \\
4.6 e-47\end{array}$ & $\begin{array}{c}p= \\
2.8 \mathrm{e}-39\end{array}$ \\
\hline $\begin{array}{r}\text { Mean Temp } \\
\left({ }^{\circ} \mathrm{C}\right)\end{array}$ & 15.1 & 15.1 & 15.3 & 15.2 & 16.6 & 16.4 & 18.2 & 18.2 & $p=1$ & $\begin{array}{c}p= \\
2.2 e-48\end{array}$ & $\begin{array}{c}p= \\
1.2 e-36\end{array}$ \\
\hline $\begin{array}{r}\text { Temp } \\
\text { Standard } \\
\text { Deviation }\left({ }^{\circ} \mathrm{C}\right)\end{array}$ & 1.6 & 1.6 & 2.1 & 2.4 & 1.7 & 1.6 & 1.2 & 1.2 & $p=0.90$ & $p=0.05$ & $p=1$ \\
\hline $\begin{array}{r}\text { Mean Salinity } \\
\text { (ppt) }\end{array}$ & 30.2 & ${ }^{*} 29.1$ & 23.4 & failed & failed & 24.7 & 27.3 & *24.4 & $\begin{array}{l}{ }^{*} \text { Not } \\
\text { tested }\end{array}$ & $\begin{array}{c}{ }^{*} \mathrm{p}= \\
2.3 \mathrm{e}-54\end{array}$ & $p=0.30$ \\
\hline $\begin{array}{r}\text { Salinity } \\
\text { Standard } \\
\text { Deviation } \\
\text { (ppt) }\end{array}$ & 0.4 & ${ }^{*} 0.34$ & 1.3 & failed & failed & 1.2 & 0.70 & *1.1 & $\begin{array}{l}{ }^{*} \text { Not } \\
\text { tested }\end{array}$ & $\begin{array}{c}{ }^{*} p= \\
2.6 e-3\end{array}$ & $p=0.12$ \\
\hline
\end{tabular}


bioRxiv preprint doi: https://doi.org/10.1101/432542; this version posted January 26,2019 . The copyright holder for this preprint (which was not certified by peer review) is the author/funder, who has granted bioRxiv a license to display the preprint in perpetuity. It is made available under aCC-BY-ND 4.0 International license.

Fidalgo Bay daily mean temperature

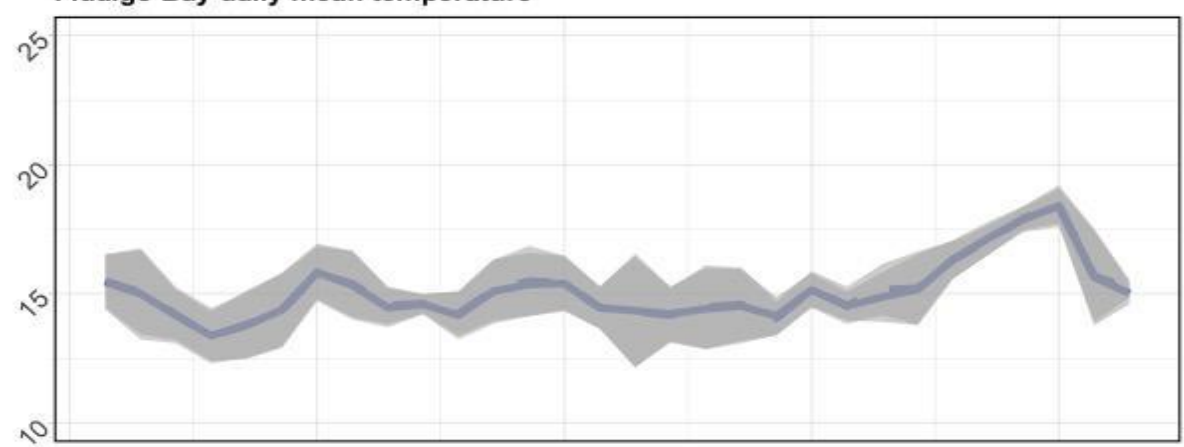

Port Gamble Bay daily mean temperature

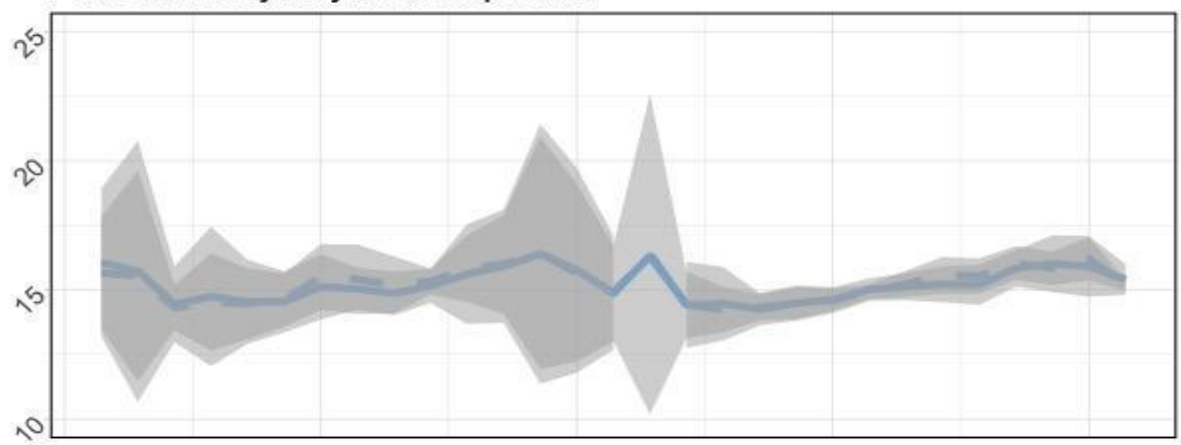

Case Inlet daily mean temperature

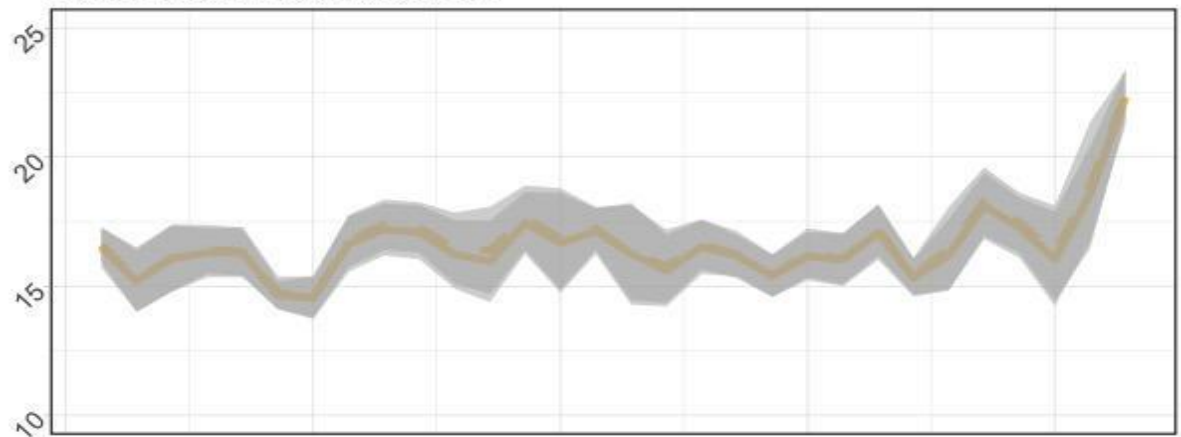

Willapa Bay daily mean temperature

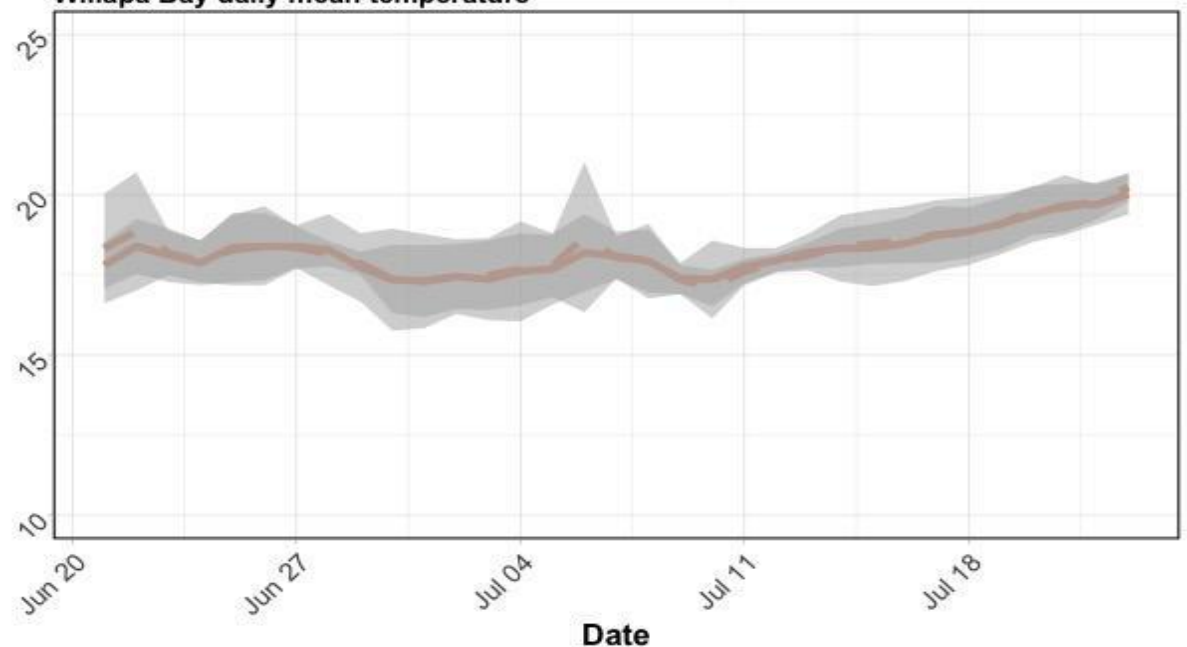

Date

Supplemental Figure 1: Daily mean temperature in eelgrass (dashed lines) and unvegetated (solid lines) across bays during geoduck deployment. Gray ribbons denote standard deviations per day. 
bioRxiv preprint doi: https://doi.org/10.1101/432542; this version posted January 26,2019 . The copyright holder for this preprint (which was not certified by peer review) is the author/funder, who has granted bioRxiv a license to display the preprint in perpetuity. It is made available under aCC-BY-ND 4.0 International license.

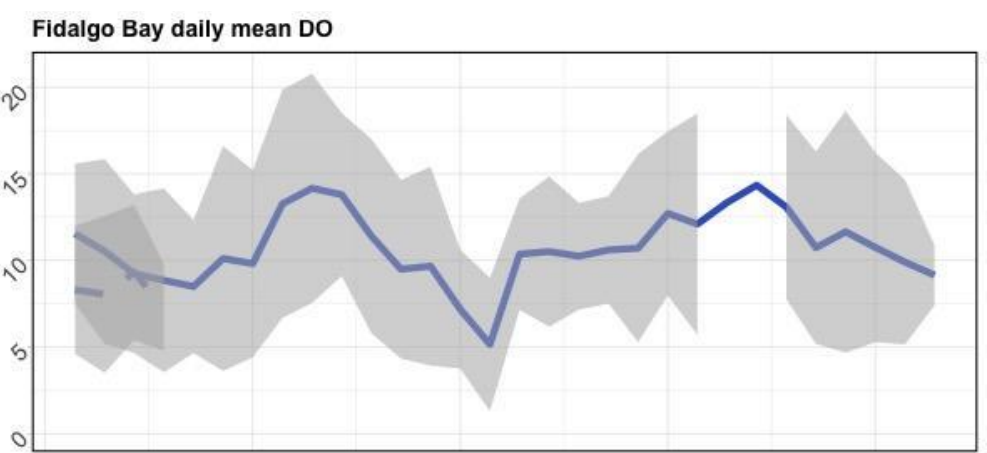

Port Gamble Bay daily mean Do
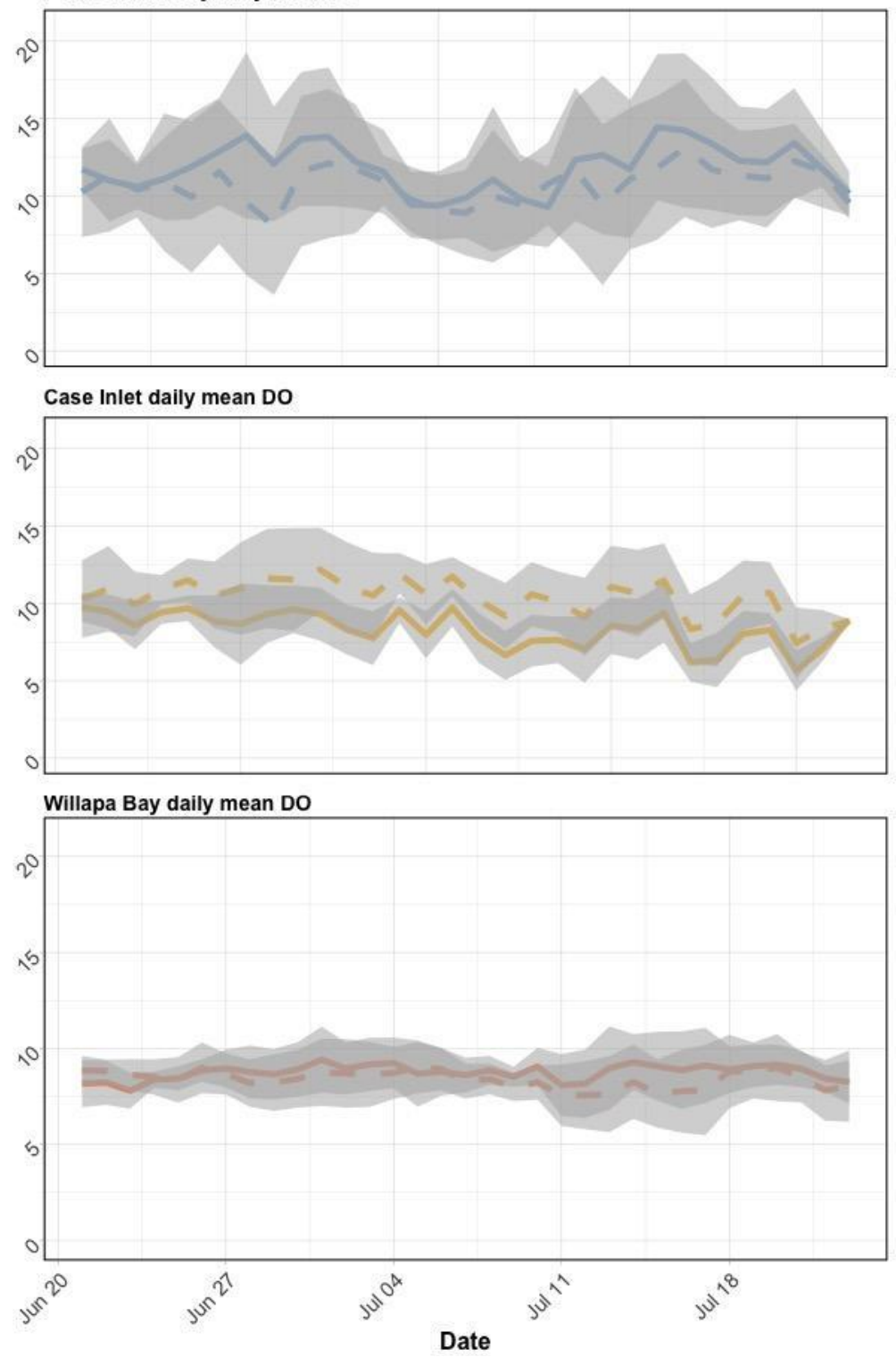

Supplemental Figure 2: Daily mean DO in eelgrass (dashed lines) and unvegetated (solid lines) across bays during geoduck deployment. Gray ribbons denote standard deviations per day. Fidalgo Bay eelgrass probe failed towards the beginning of the outplant period. 
bioRxiv preprint doi: https://doi.org/10.1101/432542; this version posted January 26, 2019. The copyright holder for this preprint (which was not certified by peer review) is the author/funder, who has granted bioRxiv a license to display the preprint in perpetuity. It is made available under aCC-BY-ND 4.0 International license.
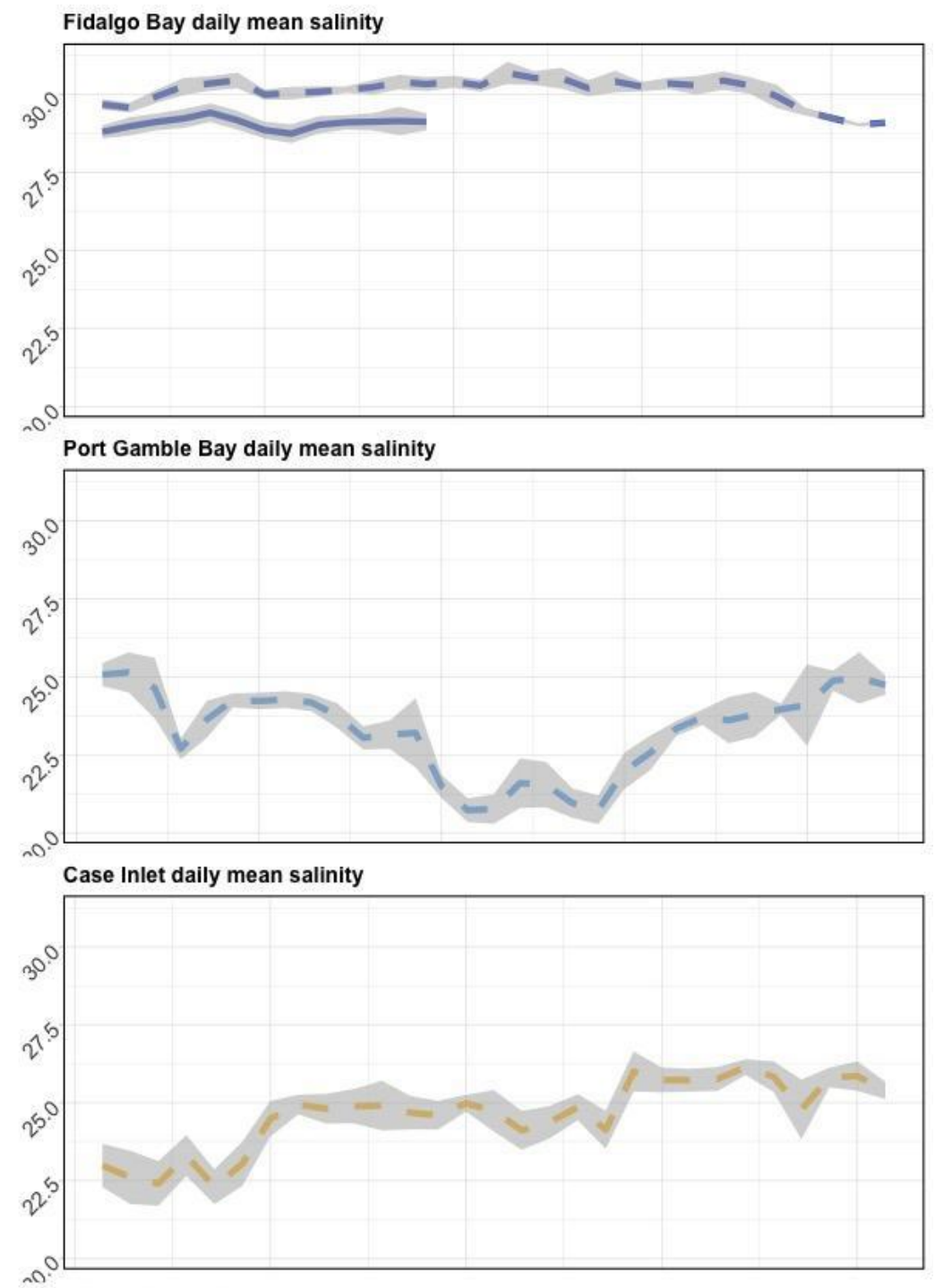

Willapa Bay daily mean salinity

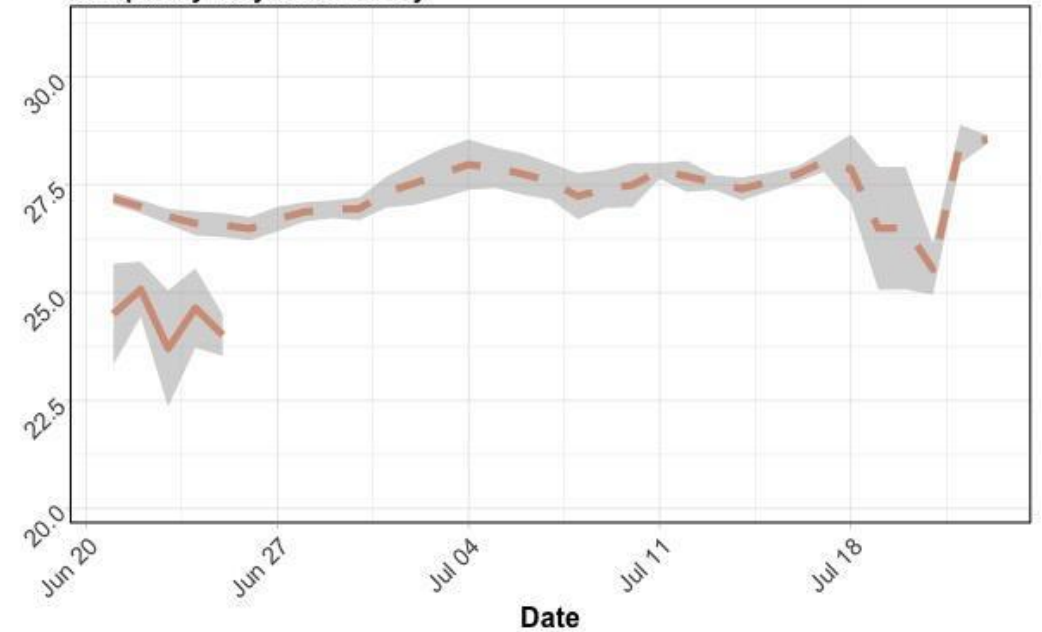

Supplemental Figure 3: Daily mean salinity in eelgrass (dashed lines) and unvegetated (solid lines) across bays during geoduck deployment. Gray ribbons denote standard deviations per day. Salinity probes failed at several locations; no habitat comparisons were made. 
Supplemental Table 2: SRM protein ANOVA results by Region (FB/PGB vs. CI/WB), Bay, and Habitat for all proteins combined, then each protein individually, with $\operatorname{Pr}(>\mathrm{F})$-adjusted calculated via the Bonferroni

Correction. Bold = significantly different abundance. Habitat was tested using 2-way ANOVA with abundance $\sim$ Bay*Habitat.

\begin{tabular}{|c|c|c|c|c|c|c|c|}
\hline & $\begin{array}{c}\text { Compariso } \\
\mathbf{n}\end{array}$ & Df & Sum Sq & Mean Sq & F value & $\operatorname{Pr}(>\mathrm{F})$ & P.adj \\
\hline \multirow[t]{3}{*}{ all peptides combined } & $\begin{array}{l}\text { North vs. } \\
\text { South }\end{array}$ & 1 & 18.2 & 18.2 & 10.9 & 0.00010 & 0.0014 \\
\hline & Bay & 3 & 34.2 & 11.4 & 7.0 & 0.00012 & 0.0017 \\
\hline & Habitat & 1 & 1.2 & 1.2 & 0.75 & 5.4 & 14 \\
\hline \multirow[t]{3}{*}{ arachidonate } & $\begin{array}{l}\text { North vs. } \\
\text { South }\end{array}$ & 1,133 & 7.4 & 7.4 & 1.3 & 0.26 & 3.6 \\
\hline & Bay & 3,131 & 60 & 20 & 3.7 & 0.014 & 0.20 \\
\hline & Habitat & 1,130 & 2.2 & 2.2 & 0.40 & 0.53 & 7.4 \\
\hline \multirow[t]{3}{*}{ catalase } & $\begin{array}{l}\text { North vs. } \\
\text { South }\end{array}$ & 1,128 & 8.6E-05 & 8.6E-05 & 0.46 & 0.50 & 7.0 \\
\hline & Bay & 3,126 & 0.00019 & $6.4 \mathrm{E}-05$ & 0.34 & 0.79 & 11 \\
\hline & Habitat & 1,125 & $1.4 \mathrm{E}-08$ & $1.4 \mathrm{E}-08$ & 7.4E-05 & 0.99 & 14 \\
\hline \multirow[t]{3}{*}{ cytochrome P450 } & $\begin{array}{l}\text { North vs. } \\
\text { South }\end{array}$ & 1,133 & 0.0065 & 0.0065 & 0.96 & 0.33 & 4.6 \\
\hline & Bay & 3,131 & 0.015 & 0.0051 & 0.76 & 0.52 & 7.3 \\
\hline & Habitat & 1,130 & 0.0085 & 0.0085 & 1.3 & 0.26 & 3.7 \\
\hline \multirow[t]{3}{*}{ glycogen phosphorylase } & $\begin{array}{l}\text { North vs. } \\
\text { South }\end{array}$ & 1,133 & 94 & 94 & 1.05 & 0.31 & 4.3 \\
\hline & Bay & 3,131 & 459 & 153 & 1.7 & 0.16 & 2.3 \\
\hline & Habitat & 1,130 & 114 & 114 & 1.3 & 0.26 & 3.6 \\
\hline \multirow[t]{3}{*}{ HSP90-alpha } & $\begin{array}{l}\text { North vs. } \\
\text { South }\end{array}$ & 1,133 & 421,443 & 421,443 & 21 & 1.3E-05 & 0.00018 \\
\hline & Bay & 3,131 & 477,740 & 159,247 & 7.8 & 7.83E-05 & 0.0011 \\
\hline & Habitat & 1,130 & 567 & 567 & 0.028 & 0.87 & 12 \\
\hline \multirow[t]{3}{*}{$\begin{array}{l}\text { protein disulfide } \\
\text { isomerase }\end{array}$} & $\begin{array}{l}\text { North vs. } \\
\text { South }\end{array}$ & 1,84 & 3.8 & 3.8 & 5.55 & 0.021 & 0.29 \\
\hline & Bay & 3,82 & 4.6 & 1.5 & 2.2 & 0.10 & 1.4 \\
\hline & Habitat & 1,81 & 0.01 & 0.006 & 0.0078 & 0.93 & 13 \\
\hline
\end{tabular}




\begin{tabular}{|c|c|c|c|c|c|c|c|}
\hline \multirow[t]{3}{*}{ puromycin-sensitive } & $\begin{array}{l}\text { North vs. } \\
\text { South }\end{array}$ & 1,130 & 0.94 & 0.94 & 9.1 & 0.0031 & 0.043 \\
\hline & Bay & 3,128 & 1.2 & 0.40 & 3.87 & 0.011 & 0.15 \\
\hline & Habitat & 1,127 & 0.09 & 0.089 & 0.87 & 0.35 & 4.9 \\
\hline \multirow[t]{3}{*}{$\begin{array}{l}\text { sodium/potassium } \\
\text { transporting ATPase }\end{array}$} & $\begin{array}{l}\text { North vs. } \\
\text { South }\end{array}$ & 1,88 & 0.65 & 0.65 & 0.42 & 0.52 & 7.2 \\
\hline & Bay & 3,86 & 3.2 & 1.06 & 0.68 & 0.56 & 7.9 \\
\hline & Habitat & 1,85 & 0.85 & 0.85 & 0.55 & 0.46 & 6.5 \\
\hline \multirow[t]{3}{*}{ superoxide dismutase } & $\begin{array}{l}\text { North vs. } \\
\text { South }\end{array}$ & 1,66 & 0.0012 & 0.0012 & 1.8 & 0.18 & 2.5 \\
\hline & Bay & 3,64 & 0.0020 & 0.00067 & 1.02 & 0.39 & 5.5 \\
\hline & Habitat & 1,63 & $5.4 \mathrm{E}-05$ & $5.4 \mathrm{E}-05$ & 0.081 & 0.78 & 11 \\
\hline \multirow[t]{3}{*}{$\begin{array}{c}\text { trifunctional enzyme } \beta \text { - } \\
\text { subunit }\end{array}$} & $\begin{array}{l}\text { North vs. } \\
\text { South }\end{array}$ & 1,88 & 252 & 252 & 11.1 & 0.0013 & 0.018 \\
\hline & Bay & 3,86 & 345 & 115 & 5.19 & 0.0024 & 0.034 \\
\hline & Habitat & 1,85 & 22 & 22 & 1.0 & 0.32 & 4.5 \\
\hline
\end{tabular}

Supplemental Table 3: Mean coefficients of variation of SRM transition abundance for each protein, location

\begin{tabular}{|l|l|l|l|l|l|l|l|l|}
\hline Protein & CI-B & CI-E & FB-B & FB-E & PG-B & PG-E & WB-B & WB-E \\
\hline arachidonate 5-lipoxygenase & 0.84 & 0.57 & 0.44 & 0.33 & 0.46 & 0.64 & 0.48 & 0.58 \\
\hline catalase & 0.61 & 0.52 & 0.47 & 0.42 & 0.50 & 0.66 & 0.50 & 0.43 \\
\hline cytochrome P450 & 0.74 & 0.57 & 0.38 & 0.43 & 0.26 & 0.58 & 0.56 & 0.46 \\
\hline glycogen phosphorylase (muscle form) & 0.55 & 0.49 & 0.35 & 0.35 & 0.37 & 0.61 & 0.51 & 0.47 \\
\hline heat shock protein 70 & 0.59 & 0.61 & 0.20 & 0.33 & 0.37 & 0.44 & 0.45 & 0.38 \\
\hline heat shock protein 90-alpha & 0.70 & 0.62 & 0.32 & 0.40 & 0.45 & 0.52 & 0.50 & 0.49 \\
\hline protein disulfide isomerase & 0.63 & 0.50 & 0.38 & 0.31 & 0.38 & 0.70 & 0.41 & 0.43 \\
\hline peroxiredoxin-1 & 0.56 & 0.46 & 0.31 & 0.33 & 0.42 & 0.46 & 0.40 & 0.36 \\
\hline puromycin-sensitive aminopeptidase & 0.69 & 0.52 & 0.39 & 0.40 & 0.42 & 0.51 & 0.44 & 0.42 \\
\hline ras-related protein rab-11B & 0.61 & 0.43 & 0.30 & 0.33 & 0.42 & 0.63 & 0.57 & 0.54 \\
\hline Na/K transporting ATPase & 0.70 & 0.58 & 0.30 & 0.36 & 0.40 & 0.62 & 0.51 & 0.44 \\
\hline Superoxide dismutase & 0.49 & 0.53 & 0.49 & 0.57 & 0.30 & 0.71 & 0.46 & 0.44 \\
\hline Trifunctional Enzyme $\beta-s u b u n i t$ & 0.61 & 0.48 & 0.41 & 0.38 & 0.46 & 0.63 & 0.52 & 0.53 \\
\hline
\end{tabular}


bioRxiv preprint doi: https://doi.org/10.1101/432542; this version posted January 26,2019 . The copyright holder for this preprint (which was not certified by peer review) is the author/funder, who has granted bioRxiv a license to display the preprint in perpetuity. It is made available under aCC-BY-ND 4.0 International license.

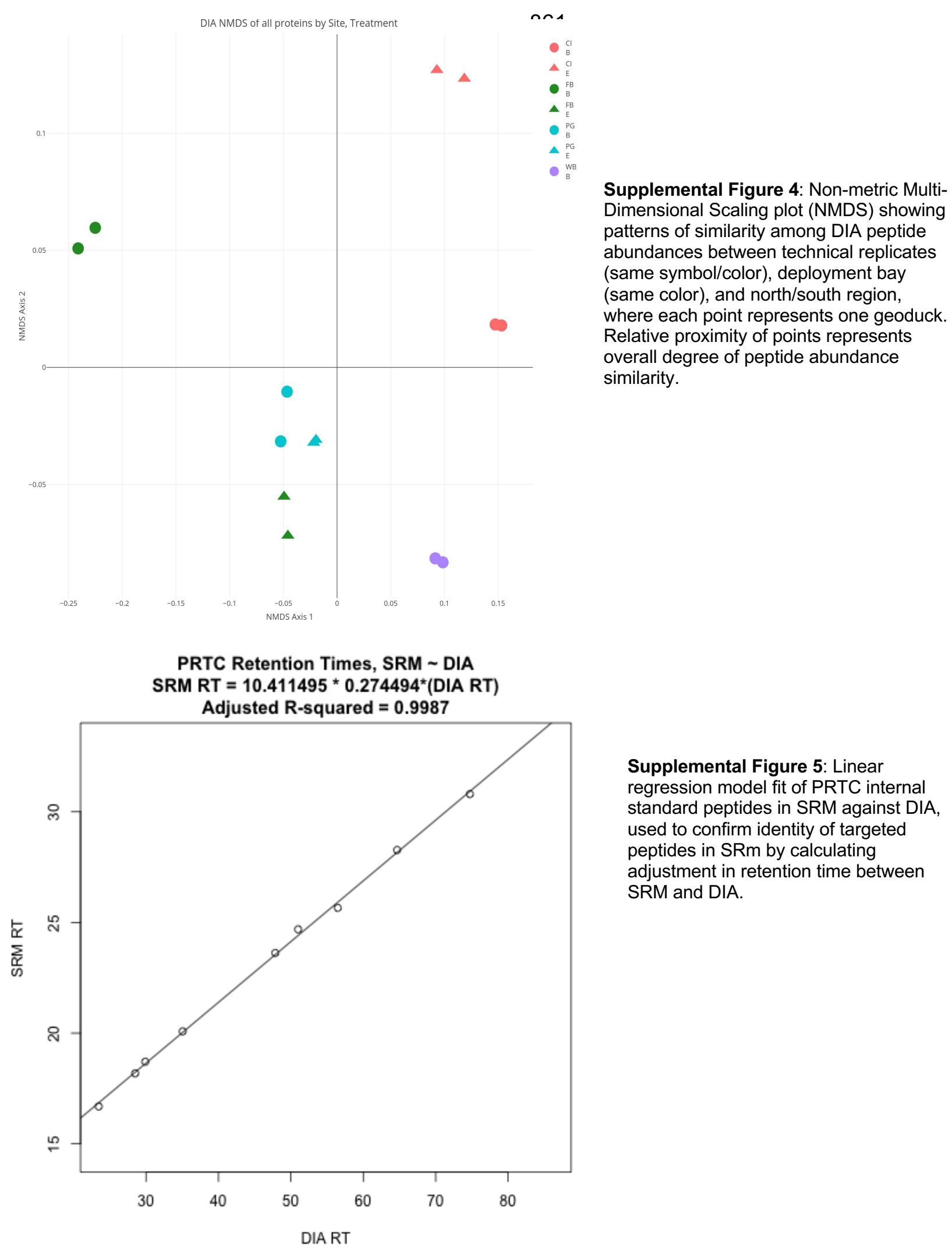


Supplemental Figure 6 (Interactive, online): Dilution curve peptide abundance ratios regressed against predicted ratios from serial sample dilutions. Peptides with slope coefficient $0.2<x<1.5$ and adjusted R2 $>0.7$ were included in analysis. Link to interactive figure: http://owl.fish.washington.edu/generosa/Generosa DNR/Dilution-Curve-Transitions.html

Supplemental Figure 7 (Interactive, online): Non-metric Multi-Dimensional Scaling plot (NMDS) of SRM technical replicates. Link to interactive figure:

http://owl.fish.washington.edu/generosa/Generosa DNR/NMDS-technical-replicate.html

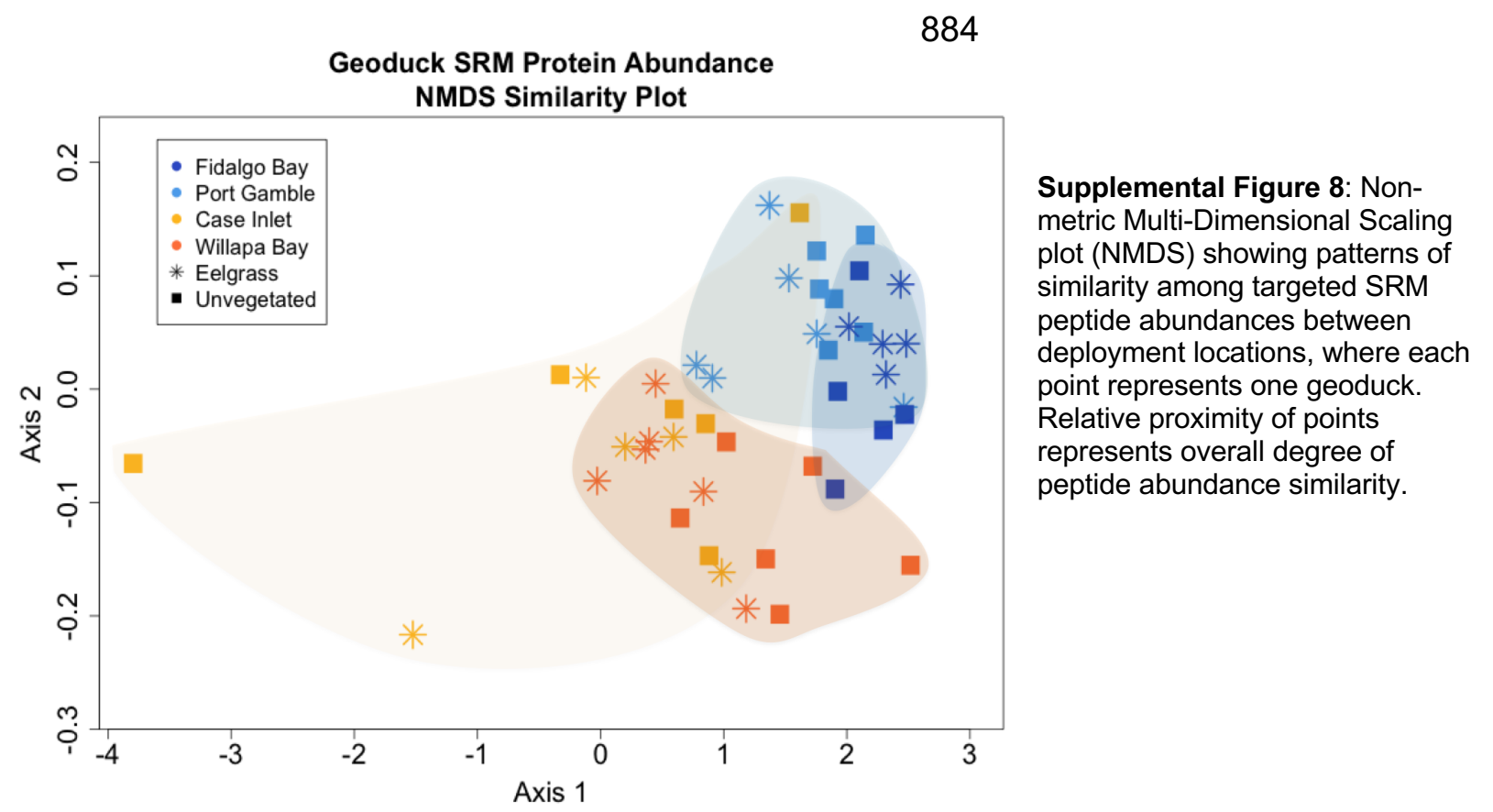

